THE IMPACT OF OUTCOME ORIENTATION AND JUSTICE CONCERNS ON TAX COMPLIANCE: THE ROLE OF TAXPAYERS' IDENTITY

Michael Wenzel

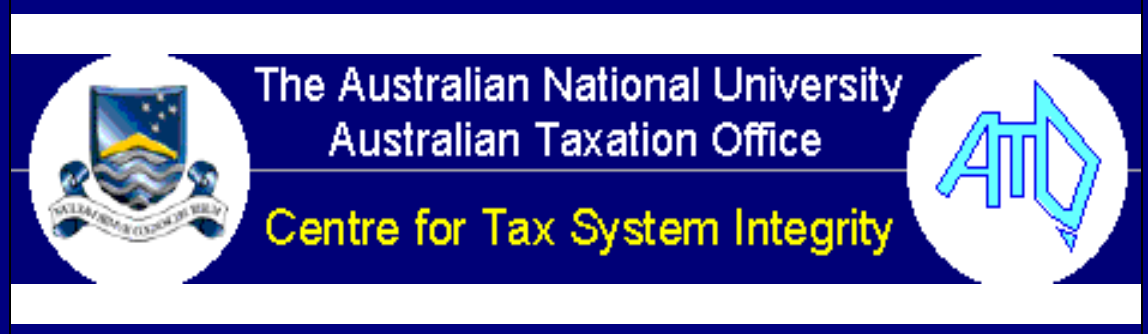

WORKING PAPER No 6

June 2001 


\title{
THE IMPACT OF OUTCOME ORIENTATION AND JUSTICE CONCERNS ON TAX COMPLIANCE: THE ROLE OF TAXPAYERS' IDENTITY
}

\author{
Michael Wenzel
}

SERIES EDITOR

Tina Murphy

\author{
Centre for Tax System Integrity \\ Research School of Social Sciences \\ Australian National University \\ Canberra, ACT, 0200
}

ISBN 0642768056

ISSN 1444-8211

\section{WORKING PAPER No 6}

June 2001 
(C) Centre for Tax System Integrity, Research School of Social Sciences, Australian National University 2001

(C) Commonwealth of Australia 2001

National Library of Australia

Cataloguing-in-Publication data:

Wenzel, M., 1966-.

The impact of outcome orientation and justice concerns on tax compliance: The role of taxpayers' identity.

Bibliography

ISBN 0642768056

1. Taxpayer Compliance - Australia. 2. Tax Collection Australia. I. Centre for Tax System Integrity. II Title.

(Series: Working paper (Australian National University.

Centre for Tax System Integrity); no.6).

336.2910994

If you would like to make any comments on this working paper please contact the author directly within 90 days of publication.

\section{Disclaimer}

This article has been written as part of a series of publications issued from the Centre for Tax System Integrity. The views contained in this article are representative of the author only. The publishing of this article does not constitute an endorsement of or any other expression of opinion by the Australian National University or the Commissioner of Taxation of the author's opinion. The Australian National University and the Commissioner of Taxation do not accept any loss, damage or injury howsoever arising that may result from this article. This article does not constitute a public or private ruling within the meaning of the Taxation Administration Act 1953, nor is it an advance opinion of the Commissioner of Taxation. 


\section{THE CENTRE FOR TAX SYSTEM INTEGRITY WORKING PAPERS}

The Centre for Tax System Integrity (CTSI) is a specialized research unit set up as a partnership between the Australian National University (ANU) and the Australian Taxation Office (Tax Office) to extend our understanding of how and why cooperation and contestation occur within the tax system.

This series of working papers is designed to bring the research of the Centre for Tax System Integrity to as wide an audience as possible and to promote discussion among researchers, academics and practitioners both nationally and internationally on taxation compliance.

The working papers are selected with three criteria in mind: (1) to share knowledge, experience and preliminary findings from research projects; (2) to provide an outlet for policy focused research and discussion papers; and (3) to give ready access to previews of papers destined for publication in academic journals, edited collections, or research monographs.

Series Editor:

Tina Murphy 


\begin{abstract}
While previous research has yielded evidence for the impact of justice perceptions on tax compliance, the findings were not always consistent. The present paper suggests a more differentiated view on the basis of two congenial justice theories. These theories argue that taxpayers are more concerned about procedural and distributive justice, and less about personal outcomes, when they identify strongly with the inclusive category within which procedures and distributions apply. Regression analyses of survey data from 2040 Australian citizens showed that two forms of tax compliance (pay income reporting and tax minimisation) were determined by self-interest variables. For two other forms (non-pay income and deductions), inclusive identification had an additional effect and moderated the effects of self-interest and justice variables as predicted. Implications for theories of justice motivation and the practice of compliance enforcement are discussed.
\end{abstract}




\section{The impact of outcome orientation and justice concerns on tax compliance: The role of taxpayers' identity.}

\section{Michael Wenzel}

Human life is organised in various more or less abstract collectives, from families, clubs, work organisations and communities to nations and supranational associations. These collectives have their own goals, agendas and policies. Their realisation, however, depends on contributions from and cooperation between members. Rules and laws may explicitly prescribe such contributions and cooperation, but they are ineffectual if not obeyed. Noncompliance jeopardises the collective project and, at least from the point of view of the collective, can be utterly destructive.

A prime example is non-compliance in the area of taxation (Andreoni, Erard \& Feinstein, 1998). A tax system is meant to provide the revenue necessary for pursuing collective goals like social security, economic prosperity and redistribution of wealth, internal and national safety, and cultural life. Non-compliance not only jeopardises funding for these projects, but insofar as it differs between social groups, non-compliance may also directly contribute to social inequality. Tax non-compliance is indeed considered a significant problem, even though its magnitude can only be estimated. For instance, for the year 1992, the United States Internal Revenue Service estimated a 'gross individual income tax gap' (that is, the difference between individual income taxes owed and taxes paid voluntarily and on time) of $\$ 93$ billion to $\$ 95$ billion (Internal Revenue Service, 1997). This translates into an individual non-compliance rate of $17 \%$, whereas $83 \%$ of taxes owed were paid voluntarily and on time.

The problem of tax non-compliance is substantial and has therefore stimulated a lot of research into the underlying factors and processes (Roth, Scholz \& Witte, 1989). This research has been dominated by economic models that conceive of taxpayers as rational actors who are basically (non)compliant if this pays off for them (e.g., Allingham \& Sandmo, 1972). However, more recent research pointed to the limitations of this perspective and the relevance of more social factors like norms, trust and morality (e.g., Cowell, 1992; Cullis \& Lewis, 1997; Gordon, 1989; Grasmick \& Bursik, 1990; Scholz \& Lubell, 1998). More specifically, researchers stressed the role of perceptions of justice and fairness, finding that taxpayers are less likely to be compliant with a tax system they consider unjust, unfair 
and thus illegitimate (e.g., Alm, Jackson \& McKee, 1993; Cowell, 1992; Falkinger, 1995; Kinsey, Grasmick \& Smith, 1991; Roberts \& Hite, 1994).

Not surprisingly, empirical research was mainly concerned with demonstrating the general relevance of social factors such as perceived justice and fairness. However, it now seems vital to address the more precise conditions of their relevance. When do justice concerns matter more than factors of individual outcome maximisation? For whom is the justice of the tax system relevant and why? We cannot assume that processes of tax compliance are the same for all taxpayers and under all conditions, implying the need for 'responsive regulation' (Braithwaite \& Braithwaite, 2000). The present research attempts to contribute to the theoretical differentiation required. It builds particularly on recent theories of procedural and distributive justice that stress the role of social identity for justice motivation versus outcome orientation.

The attempted differentiation will be threefold. First, we will distinguish between various aspects of instrumental and justice considerations and test for their comparative predictive value for tax compliance. Second, we will distinguish between various forms of tax compliance and test for the generality of the effects. Third, we will test for the moderating impact of taxpayers' social identity in terms of the inclusive category within which the tax system is applied; namely, the nation.

\section{Forms of tax compliance}

Researchers usually distinguish between tax non-compliance and tax evasion. Evasion refers to deliberate criminal non-fulfilment of tax liabilities, whereas non-compliance is a broader term and also includes unintended (although still unlawful) failure to meet tax obligations, for instance, due to misinformation, misunderstanding or calculation errors (Hessing, Kinsey, Elffers \& Weigel, 1988). However, the distinction is not always clear, for instance, in cases where taxpayers try to bend the rules and find loopholes with the intention of paying less tax (against the spirit of the rules) while not wanting to do something illegal (according to the letter of the law). In the present research we are concerned with intentional taxpaying behaviour (on which respondents can give self-reports) and define it as 'non-compliant' if it is not favourable to the tax system and thus non-cooperative towards the collective. Its primary form is of course tax evasion. 
However, even types of tax evasion may be further differentiated, not only because different types may be available to different groups of taxpayers, but also because these types could have different qualities and involve different processes. Interventions to increase compliance would then have to be specifically addressed at each of these types of tax evasion (Kidder \& McEwen, 1989). First, while some acts of evasion involve an unlawful commission (e.g., a false statement on deductions), others may involve an omission (e.g., not reporting some cash income); the latter could be considered less serious (Christensen \& Hite, 1997; see also Kahneman \& Miller, 1986). Second, perceptions of lawfulness and legitimacy can diverge (objective vs. subjective justice; see Lind \& Tyler, 1988). While people may find some unlawful acts of evasion illegitimate according to their concept of right and wrong (e.g., exaggerating deductions), they may consider some laws to be wrong and regard respective acts of evasion, even though unlawful, as morally justified (e.g., under-reporting social security allowances). Third, some acts of evasion may be clearly illegal whereas others may be borderline cases and their illegality unclear (e.g., certain tax minimisation strategies).

The present study will not be concerned with a conceptual differentiation of forms of tax compliance; this task has been undertaken elsewhere (Braithwaite, Reinhart, Braithwaite \& Williams, 2001). However, multiple forms of tax compliance will be investigated in parallel to test for differential versus consistent effects of the predictor variables. Similar effects would suggest generality of the processes underlying tax compliance. Differing effects would suggest that the processes have more to do with specific circumstances of the various forms, which would thus have to be taken into account for an understanding of the processes. The present research used a variety of measures of tax non-compliance, from under-reporting of various forms of income to exaggerations of deduction and rebate claims, and the pursuit of tax minimisation strategies.

\section{The rational actor}

Most research on tax evasion follows an economic self-interest model as initially outlined by Allingham and Sandmo (1972). It understands taxpayers as rational actors who want to maximise their individual outcomes. The taxpayer's choice is between compliance, with a certain loss in the form of the taxes paid, and tax evasion, with the chance of a relative gain if the evasion is undetected or of an even greater loss if the evasion is detected and 
penalised. In line with the model, empirical studies found that tax compliance increased with detection probability or audit probability (note that the latter does not strictly imply detection; e.g., De Juan, Lasheras \& Mayo, 1994; Friedland, 1982; Kinsey \& Grasmick, 1993; Mason \& Calvin, 1984; Webley \& Halstead, 1986). However, there were also some negative findings (Dubin, Graetz \& Wilde, 1987; Dubin \& Wilde, 1988; for a critical review, see Fischer, Wartick \& Mark, 1992). There is also some evidence that tax compliance increases with penalty rates (De Juan et al., 1994; Friedland, Maital \& Rutenberg, 1978; Klepper \& Nagin, 1989; Schwartz \& Orleans, 1967). However, the evidence is even more ambiguous on this question (Friedland, 1982; Spicer \& Lundstedt, 1976; Varma \& Doob, 1998).

Despite its apparent plausibility, the self-interest model and its implied regulatory approach of deterrence may be criticised for its one-sided focus on individual outcome maximisation (see Lewis, 1982). It ignores the fact that voluntary tax compliance requires some degree of cooperation between taxpayers and tax authorities that may be undermined by a heavyhanded regulatory approach (Sheffrin \& Triest, 1992; Strümpel, 1969). Furthermore, the self-interest model is overly individualistic (Cowell, 1992) in that it denies that taxpayers might not only be concerned with their individual outcomes, but also with their social reputation (Grasmick \& Bursik, 1990), the tax-funded outcomes for the collective (Alm et al., 1993) and justice and fairness (Kinsey et al., 1991). Thus the important question is: When are taxpayers primarily interested in maximising their individual outcomes by evading taxes while avoiding penalties, and when is their taxpaying behaviour based more on social motives?

Taxpaying behaviour can be regarded as a social dilemma (Dawes, 1980) where it appears economically most rational for individuals to evade taxes if possible and yet profit from the public goods funded by the tax system. However, if all individuals followed this rationality, the tax system would collapse, public goods would not be available and everybody would be even worse off than if they cooperated by paying their taxes (Elffers, 2000; Weigel, Hessing \& Elffers, 1987). Social psychological research on cooperation and social dilemmas suggests that cooperation is greater when participants share membership in a relevant social group (Brewer \& Kramer, 1986; Brewer \& Schneider, 1990). In fact, it is argued that social identification transforms the self and thus actual self-interest, with a more collective self- 
definition implying a greater concern for outcomes of the collective and the welfare of other members of the collective (Brewer, 1991; Morrison, 1997).

In the context of taxation, it is therefore predicted that (hypothesis 1) identification with the collective to which taxes are contributed and within which public goods are shared, that is national identification, will be related to more cooperative taxpaying behaviour and compliance. Following the self-interest model, (hypothesis 2a) deterrence and outcome favourability should increase tax compliance. However, assuming that collective identification transforms self-interest so that taxpayers are less concerned with maximising their immediate individual outcomes, it is predicted more specifically that (hypothesis $2 b$ ) deterrence and individual outcome favourability will have a more positive impact on tax compliance when taxpayers identify less rather than more strongly with the relevant collective (i.e., their nation). In the present study, deterrence follows an expectancy-value model and is conceptualised as a multiplicative combination of perceived probability of detection, perceived probability of certain legal consequences and the evaluation of the severity of these consequences. While deterrence refers to anticipated consequences of noncompliance and may be conceived of as reactive, a more proactive aspect of individual selfinterest is the perceived favourability of the tax system for oneself, or the degree to which decisions of the tax authority are favourable to oneself. The more taxpayers think tax decisions are (already) favourable to themselves, the less they should expect to gain from tax non-compliance. Despite the differentiation between proactive and reactive self-interest considerations, there is no theoretical reason why hypotheses $2 \mathrm{a}$ and $2 \mathrm{~b}$ should not hold for both outcome favourability and deterrence.

Whether in regard to individual or collective self-interest, so far we have assumed that taxpayers would be solely concerned about maximising their self-interest (even though in relation to differently defined selves and self-interests). However, taxpayers may also be concerned with issues of justice and fairness. 


\section{Concerns for procedural justice}

There is strong evidence across various contexts that perceived fairness of the procedures involved in decision-making and allocation processes affect general satisfaction, support for decision-makers and allocators, and acceptance of, or compliance with, the decision (see Tyler, Boeckmann, Smith \& Huo, 1997). In an early approach to procedural justice, Thibaut and Walker (1975) viewed process and decision control as core criteria of procedural fairness; that is, the possibility to voice one's view and to have an input in the final decision, respectively. People would desire process and decision control because it would give them control over outcomes. From this perspective, procedural justice would not be truly independent from self-interest, but rather instrumental to outcome maximisation. More recently, Lind and Tyler (1988) criticised the instrumental account for its limitations; for instance, it cannot account for procedural justice effects that are by methodological design independent from outcomes (Lind, Kanfer \& Earley, 1990). Based on social identity theory (Tajfel \& Turner, 1986), Lind and Tyler argue that people want to be treated fairly as members of a group they share with the decision-maker, because fair treatment acknowledges their membership and status in the group and maintains the values of the group. The group value approach (Tyler, 1989, 1994; Tyler et al., 1997; Tyler \& Smith, 1999) thus argues that procedural justice - in terms of neutrality, trustworthiness and respect (or status recognition) - is sought out of 'relational concerns' about one's relationship to group representatives and one's social identity as a member of the group.

Importantly, the group value approach allows for the prediction that a procedural justice motivation arising from relational concerns depends on one's degree of identification with the social category that the authorities represent and within which the procedures are applied (Huo, Smith, Tyler \& Lind, 1996; Smith \& Tyler, 1996). People should be concerned about procedural justice only as an indicator of their inclusion and status within their group when they identify with the group and their group membership relevant to their self-concept.

There are few studies so far on the impact of procedural fairness on tax compliance. Using a survey method, Porcano (1988) investigated the impact of procedural justice, relative to a number of other variables, on hypothetical or self-reported tax evasion. Procedural justice was measured by three items, asking whether taxpayers had some input in formulating tax 
laws, whether the input should be greater and whether the enforcement procedures employed by the tax authority were fair. Procedural justice did not contribute significantly to the discrimination between evaders and non-evaders as far as the hypothetical situation was concerned; self-reported past evaders even perceived the tax system to be procedurally fairer than non-evaders did. A simulation study by Alm et al. (1993) investigated experimentally whether procedural qualities of the decision of how tax revenue should be spent affected tax compliance. As predicted, there was less tax compliance when the decision was imposed on the participants rather than based on a (presumably fairer) majority rule. Similarly, in a scenario study by Tyler, Rasinski and Spodick (1985), the opportunity to voice one's opinion to a city council about the allocation of tax money positively affected perceptions of fairness of the decision process and evaluations of the council. This was the case even when there was no decision control and thus presumably little instrumental motivation (although, of course, through voicing their opinion people would hope to influence the decision). However, compliance was not an issue in this study. Likewise, other studies investigated criteria of procedural fairness applied in the area of taxation but not their effects on tax compliance (e.g., Magner, Johnson, Sobery \& Welker, 2000; Stalans \& Lind, 1997).

The present study will investigate the impact of perceived procedural fairness on tax compliance, while controlling for outcome favourability and instrumental considerations (as discussed in the previous paragraph). In line with the strong evidence in other areas, it is predicted that (hypothesis 3a) perceived procedural justice will be related to tax compliance. Furthermore, we follow the group value approach in its more specific assumption concerning the role of inclusive social identity and predict that (hypothesis $3 \mathrm{~b}$ ) perceived procedural justice will have a more positive impact on tax compliance when taxpayers identify more rather than less strongly with the relevant inclusive category (i.e., the nation).

\section{Concerns for distributive justice}

Even more so than procedural justice, distributive justice has been traditionally conceptualised as secondary or derivative to instrumental considerations (e.g., Walster, Walster \& Berscheid, 1978; see Tyler \& Smith, 1998; Wenzel, 2000a). However, more recently Wenzel (2000a, 2000b, in press) proposed an approach to distributive justice, based on self-categorisation theory (Turner, Hogg, Oakes, Reicher \& Wetherell, 1987), that complements very well the group value approach to procedural justice. 
The categorisation approach assumes that distributive justice involves categorisation processes on various levels of abstraction. Central is the inclusive category of all those considered potential recipients of the distribution. Non-differentiating justice notions (e.g., equality; see Cohen, 1987) are derived from the perception that all potential recipients are the same, in that they share membership in the inclusive category and are thus equally deserving (in an identity-defining way; Wenzel, 2000a). Conversely, equal treatment confirms their inclusion in this social category. Differentiating justice notions (e.g., equity; see Cohen, 1987) are derived from the perception that the potential recipients are differently prototypical for the inclusive category and represent to different degrees important values of that category (Wenzel, in press). Conversely, the differential treatment confirms the importance of the respective value dimension for the social category. In either situation, it is identification in terms of the inclusive category that motivates people towards justice, even at the cost of individual or group interest (Wenzel, 2000b).

A number of studies have investigated the impact of perceptions of distributive justice on tax compliance; too many to review them all here. The findings are quite mixed. An integration of the findings is further complicated by the fact that taxation involves various aspects of distributive justice, while most studies select only one or a few of them, or use overall ratings of fairness. First, there is the fairness of one's tax burden relative to others; either one's personal tax burden compared to similar others (horizontal equity; Kinsey \& Grasmick, 1993) or (largely neglected so far) the tax burden of one's group compared to other groups. For instance, Spicer and Becker (1980) found in a simulation study that disadvantageous inequity increased tax evasion and advantageous inequity decreased tax evasion (for a similar result using a survey methodology, see De Juan et al., 1994). Webley, Robben and Morris (1988) manipulated participants' relative tax-free allowances in a similar fashion but found no effect on tax evasion.

Second, there is the fairness of the relative tax burdens on different societal groups or strata (vertical equity; Kinsey \& Grasmick, 1993). This issue does not concern one's personal or group treatment but rather the overall distribution of fair tax burdens across the collective as a whole; it is thus an aspect of macrojustice (Brickman, Folger, Goode \& Schul, 1981). A related issue, not addressed in the present study, refers to the fairness of progressivity of the 
tax rates (Hite \& Roberts, 1991; Roberts \& Hite, 1994). Using survey procedures, Kinsey and Grasmick (1993) found significant effects of vertical unfairness (and unfairness of progressivity) on future intentions of tax cheating, whereas Porcano (1988), using a different and possibly less specific measure, did not find significant effects on hypothetical or past evasion.

Third, there is the issue of fairness of the taxpayer-government exchange. This could be conceptualised as an aspect of microjustice (Brickman et al., 1981) when individuals or groups of taxpayers evaluate whether the government benefits and services they receive are a fair return for the taxes they pay, compared to the benefits received and taxes paid by others. For instance, Porcano (1988) found that self-reported past evaders perceived the exchange relationship as more unfair than non-evaders did. In the present research, however, the taxpayer-government exchange will be conceptualised as an aspect of macrojustice (Brickman et al., 1981). Taxpayers will be asked to evaluate government spending, overall and across a range of areas, irrespective of the benefits they receive and the taxes they pay. For instance, Wallschutzky (1984) used an overall indicator for macrojustice exchange but did not find a significant difference between convicted evaders and a control group (nor did he find a difference for microjustice exchange indicators).

Finally, using an overall rating, Song and Yarbrough (1978) found a significant relationship between perceived fairness of the tax system and 'tax ethics', whereas Kaplan and Reckers (1985) found no effect on evasion intention or recommended penalties for evasion. Roberts and Hite (1994) even found an unpredicted positive relationship between overall fairness and admitted past non-compliance.

Unpredicted results like the latter suggest a more critical consideration of methodological issues. Generally, correlational analyses of survey data may of course always have the possible problem of omitted variables. More specifically, in the present context, fairness and justice judgments may be correlated with outcome favourability (as justice judgments are often self-serving and egocentric; Messick \& Sentis, 1983; Walster et al., 1978). In the present study we will therefore control statistically for outcome favourability and instrumental considerations in order to establish the unique effects of justice and fairness. Furthermore, distributive justice is often operationalised as a bipolar dimension, from 
unfavourable inequity over equity to favourable inequity, and is thus inherently confounded with instrumental concerns (e.g., Spicer \& Becker, 1980; Webley et al., 1988). A true effect of justice would be reflected in a curvilinear relationship between this bipolar dimension and tax compliance, with compliance being greatest at the point of equity. The present study used a bipolar measure for microjustice, but the measure was squared (and the linear effect controlled for) in order to test for the curvilinear relationship and thus the effect of genuine justice.

Given the somewhat inconsistent findings in the literature, the categorisation approach (Wenzel, 2000a, 2000b, in press), with its more specific predictions about justice motivation, seems promising for a further clarification of the role of distributive justice for tax compliance. It is predicted that (hypothesis 4a) perceptions of distributive justice (microjustice and macrojustice) will be related to tax compliance. However, following the categorisation approach, (hypothesis 4b) perceived distributive justice will have a more positive impact on tax compliance when taxpayers identify more rather than less strongly with the relevant inclusive category (i.e., their nation).

\section{Method}

\section{Participants}

The predictions were tested on the basis of data from the Community, Hopes, Fears and Action Survey (Braithwaite, 2000). The self-completion questionnaire was sent to a sample of 7754 Australian citizens drawn from the Australian electoral roll. From each state and territory a sample was randomly selected according to the ratio of enrolled electors of that state or territory relative to the total number. After subtracting cases such as where the mail was returned to sender or addressees were deceased, 7003 questionnaires were effectively sent out (for procedural details, see Mearns \& Braithwaite, 2001). After repeated appeals for participation (see below), 2040 respondents, or 29\%, returned their questionnaires. The response rate for this rather long questionnaire thus compares with experiences from other mail surveys on tax issues in Australia (Wallschutzky, 1984). Wallschutzky (1996) argues that tax surveys of the general population cannot be expected to yield a higher than $30 \%$ to $40 \%$ response rate. The participants in the final sample were aged between 18 and 88 years $(\underline{\mathrm{Md}}=48) ; 949$ were male, 1074 were female and 17 did not indicate their sex. Concerning 
occupational status, 851 were employed full time, 350 part time, 91 unemployed, 380 retired from work, 54 full-time students and 274 keeping house (there were 40 cases with missing details). Their average family income of the previous year was about A\$49000 (currently about US\$27 000).

\section{Procedure}

A professional social survey company conducted the data collection. The questionnaire was sent to respondents, together with a reply-paid envelope and an accompanying letter signed by the director of the research centre. The letter explained the intent of the study and the relationship with the Australian Taxation Office (Tax Office), and guaranteed strict confidentiality of responses. An identification number on the questionnaire allowed a targeted follow-up of cases where the questionnaire was not returned by a certain deadline. That is, where the questionnaire was not returned within about two weeks, a reminder postcard was sent out to these respondents, asking again for participation in the study. The procedure was repeated after another two weeks. About a month later, a new questionnaire was sent out to those who still had not returned their questionnaire and who might have lost it or thrown it away. Non-responders were sent reminder letters twice. This procedure aimed to ensure a reasonable response rate for a relatively long questionnaire on a sensitive issue. Excluding breaks, which were explicitly recommended at various stages of the questionnaire, respondents would have needed an estimated 1.5 hours to fill it in.

\section{Questionnaire}

The present paper deals with those survey questions relevant to six categories of variables: tax compliance, inclusive (national) identification, outcome considerations, procedural justice, distributive justice and demographic control variables. 


\section{$\underline{\text { Tax compliance }}$}

A number of measures with different response formats were used to measure various aspects of tax non-compliance. For the sake of economy, the present paper does not investigate nonlodgment or outstanding payments as instances of non-compliance (see Braithwaite et al., 2001). The items of the present study referred to the under-declaration of various forms of income (i.e., earnings, cash income, government payments, interest and dividends), exaggerated claims for deductions and rebates and general engagement in tax planning and use of specific forms of tax minimisation. Exact wording and formats of the items are given in the appendix.

\section{$\underline{\text { Inclusive identification }}$}

Two items measured inclusive identification, that is, national identification as Australians (see Haslam, 2001): 'Being a member of the Australian community is important to me' and 'I feel a sense of pride in being a member of the Australian community' $(1=$ do not agree at all, $7=$ agree completely). The items were highly correlated $(\underline{r}=.87)$ and thus scores were averaged to obtain a measure of inclusive identification. However, the measure was highly skewed and truncated at the pole of high identification; $65 \%$ of respondents had a score of 6 , 6.5 or $7(\mathrm{Mn}=6, \mathrm{M}=5.86)$. A large portion of the variance in inclusive identification would thus be located at the high identification end of the scale, which would be inappropriate for tests of predictions about the impact of a high versus low degree of inclusive identification. Therefore, the measure was dichotomised, with scores lower than or equal to the midpoint of the scale (4) defined as low identification $(\underline{n}=250)$ and scores greater than the midpoint of the scale defined as high identification $(\underline{n}=1718)$.

\footnotetext{
${ }^{1}$ Dichotomization of variables is often criticized for loss of information. The reason for using the procedure in the present context may be conceived of as focussing on the relevant information, given the empirical peculiarities of the variable. It is less relevant whether respondents indicated scale points 6 or 7 for their degree of identification (this might rather reflect some personal preference for extreme or less extreme responses); more meaningful and important is whether respondents tended towards the one or the other end of the identification scale. However, variance in this respect would be diluted by the variance of a large number of cases at the upper end of the scale, if the original scale would be used.
} 


\section{$\underline{\text { Outcome considerations }}$}

In the introduction, proactive and reactive aspects of self-interest, or outcome orientation, were distinguished. The reactive aspect refers to the perceived risk of being caught and punished for evading tax; the extent to which one feels deterred from tax evasion. Following an expectancy-value model, deterrence was defined as the product of perceived probability of detection, perceived probability of certain legal consequences and the evaluation of the severity of these consequences. The measurement of deterrence used a modified form of the measures of Varma and Doob (1998). The precise wording and format of the questions are given in the appendix. This procedure was followed for two instances of tax evasion, namely, under-reporting of cash income and untruthful claims for work-related expenses (deductions). Hence we obtained a deterrence measure for both under-reporting of cash income and exaggerations of deductions. The measures were highly correlated $(\underline{r}=.74)$.

The proactive aspect of self-interest refers to the perceived outcome favourability to oneself of the tax authority's decisions. Items were adopted from research on the group value model (e.g., Tyler, 1997): 'How often do you agree with the decisions made by the Tax Office?' and 'How often are the decisions of the Tax Office favourable to you?' ( 1 = almost never, 5 $=$ almost always). The measures were highly correlated $(\underline{\mathrm{r}}=.65)$.

\section{Procedural justice}

Procedural justice was conceptualised in line with the group value approach. The formulation of the measures followed previous research in this area (e.g., Tyler, 1997) with its distinction between the sub-concepts of respect (e.g., 'The Tax Office respects the individual's rights as a citizen'), trustworthiness (e.g., 'The Tax Office considers the concerns of average citizens when making decisions') and neutrality (e.g., 'The Tax Office gives equal consideration to the views of all Australians'). Again, the appendix contains a complete list of the measures. 


\section{Distributive justice}

The present study investigated issues of microjustice and macrojustice (Brickman et al., 1981). With regard to issues of microjustice, two questions using the same format measured perceived fairness of the tax burden of oneself and the tax burden of one's industry/occupation group: 'In your opinion, do the following people/groups pay their fair share of tax? (a) You, yourself (b) your industry/occupation group' (1 = much more than their fair share, 2 =a bit more, 3 = about their fair share, $4=$ a bit less, $5=$ much more than their fair share). For another indicator, respondents were asked about a group they considered relevant: 'Think about the people who are in the same boat as you when it comes to paying tax. In your opinion, do they pay ...?' (with the same response options as before).

With regard to issues of macrojustice, respondents were asked to rate for 16 societal categories (e.g., owner-managers of large companies, senior judges and barristers, unskilled factory workers) the extent to which they paid their fair share (again using the same scale; see appendix). Following the procedure used by Kinsey and Grasmick (1993), for each respondent the standard deviation over these ratings was calculated and used as an indicator for vertical justice. A low standard deviation means that the tax burdens of the different groups were judged similarly fair or unfair; hence unfairness would be distributed equally over the society and there would be few relative advantages of certain groups in that regard. A high standard deviation, by contrast, indicates large differences in perceived fairness of the tax burdens and thus an unfair distribution of tax fairness.

A second issue of macrojustice referred to government spending. 'The government spends taxpayers' money in many different areas. Below are just a few of these areas. For each area, do you think the government should be spending less money, keeping things as they are, or spending more money?' A list of areas followed (see appendix); for example, education, defence $(1=$ much less, 2 = less, 3 = same, $4=$ more, $5=$ much more $)$. For the purpose of the analyses reported in this paper, the measure was recoded into scores of 3,2, 1, 2 and 3 respectively, to obtain a measure of satisfaction/dissatisfaction with government spending. Another single item represented a global measure of the same issue: 'Overall, how dissatisfied or satisfied are you with the way the government spends taxpayers' money?' $(1=$ 
dissatisfied, 5 = satisfied; reverse-coded). The two measures were significantly correlated with each other $(\underline{r}=.31)$.

\section{$\underline{\text { Background variables }}$}

Respondents were asked to indicate their age, sex $(1=$ male, $2=$ female $)$, personal income and family income (each on a scale from none, 5, 10, 15, etc. to $75,100,250+$ thousand dollars).

\section{Results}

\section{Factor analyses}

\section{$\underline{\text { Tax compliance }}$}

In order to group variables measuring similar behavioural dispositions toward tax compliance, the 14 compliance measures used in this study were factor-analysed using a Principal Component Analysis with Varimax rotation (see Table 1). The analysis yielded a four-factor solution, explaining $57 \%$ of the variance. All items loaded clearly on one factor each, except for two items with substantial loadings on two factors. Factor 1 comprised four items that referred to the reporting of (1) all earned money, (2) cash-in-hand money, (3) salary and wages and (4) honorariums, etc. This factor may thus be termed tax compliance with regard to remuneration Income. Items 3 and 4, however, also each had a substantial cross-loading on the second factor. These may be attributable to the fact that the two items were measured in one block together with the following five items, using a shared response format (see appendix). Regarding their content, the two items seemed to better fit factor 1 as defined above. Rather than using only the first two unambiguous items, a four-item measure was maintained for reasons of conceptual plausibility and higher internal consistency $(\alpha=$ .62). ${ }^{2}$ Factor 2 comprised five items concerning the declaration of (1) eligible termination payments, (2) Australian government allowances, (3) Australian government pensions, (4) interest and (5) dividends. This factor thus referred to tax compliance in the declaration of non-remuneration Extra Income $(\alpha=.78)$. Factor 3 was defined by two items referring to

\footnotetext{
${ }^{2}$ A score for Income noncompliance based only on the two unambiguous items yielded basically the same results in the regression analyses as the four-measure construct.
} 
exaggerations or confidence in the legitimacy of one's deduction claims. The factor thus reflects compliance in Deduction claims $(\alpha=.51)$. Factor 4 comprised three items: Two measures asked about one's general efforts to plan one's financial affairs and minimise tax. The third item was defined as the number of specific given tax minimisation strategies respondents said they used. This factor thus reflects the use of Tax Minimisation strategies $(\alpha=.62)$. For each factor, indicators were averaged to obtain compound indicators for the four factors. In cases where indicators of the same construct differed in their response formats, items were first standardised and then averaged. 
Table 1: Factor analysis of measures of tax compliance

\begin{tabular}{|c|c|c|c|c|}
\hline Item & Factor 1 & Factor 2 & Factor 3 & Factor 4 \\
\hline Income & .81 & & & \\
\hline Cash Income & .74 & & & \\
\hline Salary, wages & .59 & $(.45)$ & & \\
\hline $\begin{array}{l}\text { Honorariums, allowances, tips, bonuses, } \\
\text { directors fees }\end{array}$ & .42 & $(.52)$ & & \\
\hline Eligible termination payments & & .73 & & \\
\hline Australian government allowances like Youth & & .76 & & \\
\hline Allowance, Austudy, Newstart & & & & \\
\hline Australian government pension. superannuation & & .74 & & \\
\hline $\begin{array}{l}\text { Pensions, and other government pensions and } \\
\text { annuities }\end{array}$ & & & & \\
\hline Interest & & .57 & & \\
\hline Dividends & & .73 & & \\
\hline Exaggeration of deductions & & & .76 & \\
\hline Illegitimacy of deduction & & & .79 & \\
\hline Effort on tax minimisation & & & & .78 \\
\hline Looked at ways to minimise tax & & & & .82 \\
\hline Various strategies on tax minimisation & & & & .65 \\
\hline Explained variance $(\%)$ & 13 & 22 & 10 & 13 \\
\hline
\end{tabular}

Note. Principal Component Analysis, Varimax rotation. Only factor loadings $\geq .4$ are displayed; cross-loadings are given in brackets. 


\section{$\underline{\text { Self-interest and justice variables }}$}

A factor analysis was also used to test for the assumed conceptual differentiation between self-interest and justice variables (see Table 2). The analysis yielded a five-factor solution explaining $63 \%$ of the variance. All items loaded as anticipated on their respective factors. Indicators of the same construct that differed in their response formats were standardised before they were averaged to obtain compound indicators for the five factors Deterrence $(\alpha=$ .85), Outcome Favourability $(\alpha=.76)$, Procedural Justice $(\alpha=.90)$, Distributive (Micro)Injustice $(\alpha=.74)$ and Macro-Injustice $(\alpha=.58)$. The interrelations and descriptive statistics (where measures were not based on standardised indicators) of all the constructs are given in Table 3.

\section{Predicting tax compliance}

Hierarchical regression analyses were applied to test the theoretical predictions. In a first step, the background variables Sex, Age, Personal Income and Family Income were used as predictors to control for demographic differences between respondents. In a second step, self-interest, justice and identification variables were introduced as predictors to test for main effects as predicted in hypotheses 1, 2a, 3a and 4a. In a third step, all product terms of self-interest and justice variables with the inclusive identification measure were introduced as predictors to test for interaction effects as predicted in hypotheses $2 \mathrm{~b}, 3 \mathrm{~b}$ and $4 \mathrm{~b}$. The results of step 3, however, are only considered when the introduction of the product terms led to a significant increase in explained variance; otherwise, we refer to step 2 for the statistics of possible main effects (Cohen \& Cohen, 1975). To reduce problems of multicollinearity due to the use of interaction terms, all predictor variables were standardised before the product terms were built. Together with a standardised criterion, this procedure also produced the appropriate standardised solution (reported here), even though the constants were non-zero (Aiken \& West, 1991).

As discussed earlier, the measure for Distributive Injustice was bipolar, ranging from unfairly disadvantaged to unfairly advantaged, with perceived fairness as the midpoint of the scale. An effect of perceived justice independent from perceived favourability would be reflected in a curvilinear relationship with tax compliance. Therefore, the square of the 
standardised measure was considered the true indicator of Distributive Injustice effects and, as such, introduced as a predictor in step 2, next to the original measure that controlled for linear effects of favourability. The hierarchical regression procedure was applied to all four indicators of tax compliance. 
Table 2: Factor analysis of measures of self-interest and justice

Item

$\underline{\text { Factor } 1}$ Factor 2 Factor 3 Factor 4 Factor 5

Deterrence-Cash

.92

Deterrence-Deductions

.92

Agreement with decisions

.83

Favourability of decisions

Tax Office (TO) respects individual's rights

.65

TO is concerned about protecting rights .77

TO considers average citizen's concerns .80

TO cares about position of taxpayers .74

TO tries to be fair when making decisions .72

TO gives equal consideration to views .66

TO gets information necessary for decisions .57

TO is generally honest with taxpayers .63

TO consults widely about changes .69

TO goes to great length to consult .67

Fairness of one's own tax burden .82

Fairness of tax burden of industry group .85

Fairness of tax burden of people in the same boat .70

Standard deviation of fairness ratings across groups

Government spending for various selected areas

Global satisfaction with government spending .58 Explained variance $(\%)$ 9 9 26 10

Note. Principal Component Analysis, Varimax rotation; only factor loadings $\geq .4$ are displayed. 


\section{Table 3: Intercorrelations and summary statistics}

\begin{tabular}{|c|c|c|c|c|c|c|c|c|c|c|c|c|c|}
\hline Variable & $\mathbf{M}$ & SD & $\mathbf{N}$ & 1 & 2 & 3 & 4 & 5 & 6 & 7 & 8 & 9 & 10 \\
\hline 1. Income $[1 ; 2]$ & 1.05 & .14 & 1621 & - & & & & & & & & & \\
\hline 2. Extra Income $[1 ; 2]$ & 1.03 & .12 & 1567 & $.39^{* * *}$ & - & & & & & & & & \\
\hline 3. Deductions & $\mathrm{n} / \mathrm{a}$ & $\mathrm{n} / \mathrm{a}$ & 1612 & $.29^{* * *}$ & $.34^{* * *}$ & - & & & & & & & \\
\hline 4. Tax Minimisation & $\mathrm{n} / \mathrm{a}$ & $\mathrm{n} / \mathrm{a}$ & 1650 & $.07^{* *}$ & $.08^{* *}$ & $.13^{* * *}$ & - & & & & & & \\
\hline 5. Incl. Identification $[1 ;$ & $2] 1.87$ & .33 & 1968 & $-.05^{*}$ & $-.11^{* * *}$ & $-.07^{* *}$ & -.01 & - & & & & & \\
\hline 6. Deterrence $[1 ; 100]$ & 47.28 & 26.27 & 1897 & $-.14^{* * *}$ & $-.09^{* * *}$ & $-.16^{* * *}$ & $-.10^{* * *}$ & $.15^{* * *}$ & - & & & & \\
\hline 7. Outcome Fav. $[1 ; 5]$ & 3.67 & 1.02 & 1923 & $-.11^{* * * *}$ & $-.05^{*}$ & $-.10^{* * *}$ & $-.09^{* * *}$ & $.10^{* * *}$ & $.06^{* *}$ & - & & & \\
\hline 8. Procedural Justice $[1 ;$ & $5] 3.11$ & .66 & 1998 & -.02 & $.06^{*}$ & -.01 & -.04 & $.12^{* * *}$ & $.10^{* * *}$ & $.48^{* * *}$ & - & & \\
\hline 9. Distrib. Injustice $[1 ; 5]$ & 2.64 & .66 & 1976 & .03 & .04 & $.07^{* *}$ & .02 & -.04 & -.04 & $.18^{* * *}$ & $.28^{* * *}$ & - & \\
\hline 10.Distrib. Inj. Squared & $\mathrm{n} / \mathrm{a}$ & $\mathrm{n} / \mathrm{a}$ & 1976 & .02 & -.00 & .02 & $.04^{\dagger}$ & -.02 & -.01 & $-.20^{* * *}$ & $-.21^{* * *}$ & $-.32^{* * *}$ & - \\
\hline 11.Macro- Injustice & $\mathrm{n} / \mathrm{a}$ & $\mathrm{n} / \mathrm{a}$ & 2035 & -.00 & -.04 & .01 & -.01 & -.01 & $.07^{* *}$ & $-.21^{* * *}$ & $-.39^{* * *}$ & $-.27^{* * *}$ & $.27^{* * *}$ \\
\hline
\end{tabular}

Note. Means for compound measures based on standardised indicators (originally with different scales) are not meaningful and not reported. Possible scale ranges, again only where applicable, are given in square brackets. Higher scores indicate greater non-compliance, identification, deterrence, outcome favourability, procedural justice and distributive injustice (for Distrib. Inj. Squared and Macro-Injustice), respectively. $\underline{\mathrm{p}}<.10, \stackrel{*}{\mathrm{p}}<.05, \stackrel{* *}{\mathrm{p}}<.01, \stackrel{* * *}{\mathrm{p}}<.001$ 


\section{$\underline{\text { Income reporting }}$}

For non-compliance in reporting one's Income, the regression analysis explained a significant portion of variance in steps 1 and 2, while the interaction terms introduced in step 3 did not further contribute significantly to the prediction of non-compliance (see Table 4). Focusing therefore on step 2, first of all, three of the background variables had a significant impact. Age had a negative impact $(\beta=-.15 ; \underline{p}<.001)$, reflecting that in particular younger respondents reported they were less compliant and more likely to under-report their income. The effect of $\operatorname{sex}(\beta=-.11 ; \underline{p}<.001)$ means that male respondents reported greater underreporting of income than females. Personal Income also had a negative effect $(\beta=-.14 ; \underline{p}<$ $.001)$, indicating that respondents with a lower income of this kind were less compliant and reported their income less correctly than respondents with higher income. Furthermore, there were significant negative effects of the two self-interest variables, Deterrence $(\beta=-.14 ; \mathrm{p}<$ $.001)$ and Outcome Favourability $(\beta=-.12 ; \mathrm{p}<.001)$. In accordance with hypothesis $2 \mathrm{a}$, perceived deterrence increased compliance; and respondents were more compliant with regard to income reporting, the more favourable to themselves they perceived Tax Office decisions to be. None of the justice or identification variables had a significant impact on this form of tax compliance. The only other significant effect was a positive effect $(\beta=.06$; $\mathrm{p}=.041)$ of the original bipolar measure of Distributive Injustice that should not be interpreted. (It was included in the analysis merely to control for a linear effect in the squared measure and, if anything, could be regarded as another indicator of outcome favourability.) 
Table 4: Hierarchical regression analyses for tax non-compliance in reporting of income

\begin{tabular}{|c|c|c|c|c|c|c|}
\hline & \multicolumn{2}{|c|}{ Step 1} & \multicolumn{2}{|c|}{ Step 2} & \multicolumn{2}{|c|}{ Step 3} \\
\hline$\underline{\mathrm{R}^{2}}$ & \multicolumn{2}{|c|}{.036} & \multicolumn{2}{|c|}{.071} & \multicolumn{2}{|c|}{.076} \\
\hline$\underline{\mathrm{R}^{2}}$ change & & & \multicolumn{2}{|c|}{.035} & \multicolumn{2}{|c|}{.005} \\
\hline Fchange ( $\underline{\mathrm{dfs}})$ & \multicolumn{2}{|c|}{$12.49(4,1323)$} & \multicolumn{2}{|c|}{$7.07(7,1316)$} & \multicolumn{2}{|c|}{$1.12(6,1310)$} \\
\hline$\underline{\text { Sig. Fchange }}$ & \multicolumn{2}{|c|}{.000} & \multicolumn{2}{|c|}{.000} & \multicolumn{2}{|c|}{.350} \\
\hline & $\beta$ & p & $\beta$ & $\mathbf{p}$ & $\beta$ & p \\
\hline Age & -.15 & .000 & -.12 & .000 & -.12 & .000 \\
\hline Sex & -.11 & .000 & -.09 & .001 & -.09 & .001 \\
\hline Personal Income & -.14 & .000 & -.15 & .000 & -.15 & .000 \\
\hline Family Income & .00 & $\underline{\mathrm{ns}}$ & -.01 & $\underline{\mathrm{ns}}$ & -.01 & $\underline{\mathrm{ns}}$ \\
\hline Identification & & & -.02 & $\underline{\mathrm{ns}}$ & -.02 & $\underline{\mathrm{nS}}$ \\
\hline Deterrence & & & -.14 & .000 & -.14 & .000 \\
\hline Outcome Fav. & & & -.12 & .000 & -.12 & .000 \\
\hline Procedural J. & & & .04 & $\underline{\mathrm{nS}}$ & .04 & $\underline{\mathrm{nS}}$ \\
\hline Distributive. Inj. & & & .06 & .041 & .07 & .024 \\
\hline Distrib. Inj. Squared & & & .01 & $\underline{\mathrm{nS}}$ & .02 & $\underline{\mathrm{nS}}$ \\
\hline Macro-Injustice & & & .05 & $\underline{\mathrm{ns}}$ & .05 & .098 \\
\hline Id.XDeterrence & & & & & .04 & $\underline{\mathrm{nS}}$ \\
\hline Id.XOutcome Fav. & & & & & .03 & $\underline{\mathrm{nS}}$ \\
\hline Id.XProc. J. & & & & & -.02 & $\underline{\mathrm{nS}}$ \\
\hline Id.X Distr. Inj. & & & & & .01 & $\underline{\mathrm{ns}}$ \\
\hline Id.XD. Inj. Squared & & & & & .02 & $\underline{\mathrm{ns}}$ \\
\hline Id.X Macro-Injustice & & & & & .03 & $\underline{\mathrm{ns}}$ \\
\hline (Constant) & -.02 & ns & -.02 & ns & -.03 & ns \\
\hline
\end{tabular}




\section{$\underline{\text { Reporting of extra income }}$}

For non-compliance in reporting Extra Income, all three steps of the regression analysis explained significant portions of variance. Thus we focus on the most complete third step (see Table 5). Personal Income was the only background variable that had a significant effect $(\beta=-.08 ; \underline{p}=.034) ;$ it indicates that again respondents with lower income reported being less compliant and less truthful about their extra income. Given the significant interaction effects in which these variables were also involved, significant first-order effects of the selfinterest and justice variables may be understood as 'average effects' across levels of inclusive identification (Aiken \& West, 1991). Specifically, Deterrence had a significant negative inhibitory effect on non-compliance $(\beta=-.07 ; \underline{p}=.014)$. Likewise, Outcome Favourability was negatively related to under-reporting of extra income $(\beta=-.09 ; \underline{p}=.004)$. These two effects were in line with hypothesis $2 \mathrm{a}$. Procedural Justice had a significant positive effect $(\beta=.12 ; \underline{p}<.001)$, contrary to hypothesis 3 a that perceptions of procedural justice would decrease non-compliance. Inclusive Identification also had a significant overall effect $(\beta=-.12 ; \mathrm{p}<.001)$; in accordance with hypothesis 1 , respondents who identified more rather than less strongly with Australians reported being more compliant.

However, all these effects would need to be considered in the light of relevant interaction effects. First, the effect of Deterrence was significantly moderated by level of Inclusive Identification $(\beta=.09 ; \underline{p}=.004)$, as predicted in hypothesis $2 \mathrm{~b}$. A simple slope analysis (see Aiken \& West, 1991) showed that Deterrence decreased non-compliance for respondents who identified less with the inclusive category $(\beta=-.16)$, but not for those highly identified $(\beta=.02) .{ }^{\text {B }}$ Paralleling this finding, there was a significant positive interaction effect of Outcome Favourability and Inclusive Identification $(\beta=.08 ; \underline{p}=.004)$. In line with hypothesis $2 \mathrm{~b}$, respondents who identified less with Australians were more compliant when decisions of the tax authority were favourable to them, but not so the highly identified respondents (simple slopes: -.18 vs. -.01 ).

\footnotetext{
${ }^{3}$ All simple slopes reported in the present paper were calculated for levels of -1 versus +1 standard deviation of Inclusive Identification.
} 
There was further an interaction effect of perceived Procedural Justice and Inclusive Identification $(\beta=-.09 ; \mathrm{p}=.006)$, in line with hypothesis $3 \mathrm{~b}$. More precisely, however, for highly identified respondents this effect only buffered the unexpected positive 'average' effect of Procedural Justice on non-compliance, while the positive effect remained for less identified respondents (simple slopes: .03 vs. .12). So, while the direction of the interaction effect is in line with the hypothesis, Procedural Justice had no overall positive effect for the highly identified. Moreover, the squared measure of perceived Distributive Injustice was related to greater non-compliance for those strongly identified as Australians, but not so for those less identified with Australians (interaction effect: $\beta=.03 ; \underline{p}=.047$; simple slopes: .05 vs. -.01$)$; this finding supported hypothesis $4 \mathrm{~b}$. 
Table 5: Hierarchical regression analyses for tax non-compliance in reporting of extra income

\begin{tabular}{|c|c|c|c|c|c|c|}
\hline & \multicolumn{2}{|c|}{ Step 1} & \multicolumn{2}{|c|}{ Step 2} & \multicolumn{2}{|c|}{ Step 3} \\
\hline$\underline{\mathrm{R}^{2}}$ & \multicolumn{2}{|c|}{.008} & \multicolumn{2}{|c|}{.038} & \multicolumn{2}{|c|}{.059} \\
\hline$\underline{\mathrm{R}^{2}}$ change & & & \multicolumn{2}{|c|}{.030} & \multicolumn{2}{|c|}{.021} \\
\hline Fchange ( $\underline{\mathrm{dfs}})$ & \multicolumn{2}{|c|}{$2.44(4,1287)$} & \multicolumn{2}{|c|}{$5.85(7,1280)$} & \multicolumn{2}{|c|}{$4.70(6,1274)$} \\
\hline Sig. Fchange & \multicolumn{2}{|c|}{.045} & \multicolumn{2}{|c|}{.000} & \multicolumn{2}{|c|}{.000} \\
\hline & $\beta$ & p & $\beta$ & p & $\beta$ & $\mathbf{p}$ \\
\hline Age & -.04 & $\underline{\mathrm{ns}}$ & -.03 & $\underline{\mathrm{ns}}$ & -.02 & $\underline{\mathrm{ns}}$ \\
\hline Sex & -.04 & $\underline{\mathrm{ns}}$ & -.04 & $\underline{\mathrm{ns}}$ & .03 & $\underline{\mathrm{ns}}$ \\
\hline Personal Income & -.09 & .017 & -.09 & .014 & -.08 & .034 \\
\hline Family Income & .01 & $\underline{\mathrm{ns}}$ & .02 & $\underline{\mathrm{ns}}$ & .02 & $\underline{\mathrm{nS}}$ \\
\hline Identification & & & -.11 & .000 & -.12 & .001 \\
\hline Deterrence & & & -.07 & .019 & -.07 & .014 \\
\hline Outcome Fav. & & & -.10 & .001 & -.09 & .004 \\
\hline Procedural J. & & & .14 & .000 & .12 & .000 \\
\hline Distributive. Inj. & & & .02 & $\underline{\mathrm{ns}}$ & .03 & $\underline{\mathrm{nS}}$ \\
\hline Distrib. Inj. Squared & & & .01 & $\underline{\mathrm{ns}}$ & .02 & $\underline{\mathrm{ns}}$ \\
\hline Macro-Injustice & & & .03 & $\underline{\mathrm{ns}}$ & .04 & $\underline{\mathrm{nS}}$ \\
\hline Id. $\times$ Deterrence & & & & & .09 & .004 \\
\hline Id.XOutcome Fav. & & & & & .08 & .004 \\
\hline Id. $\times$ Proc. J. & & & & & -.09 & .006 \\
\hline Id. $\times$ Distr. Inj. & & & & & .04 & $\underline{\mathrm{ns}}$ \\
\hline Id. $\times$ D. Inj. Squared & & & & & .03 & .047 \\
\hline Id. $\times$ Macro-Injustice & & & & & -.00 & $\underline{\mathrm{nS}}$ \\
\hline (Constant) & -.02 & ns & -.01 & ns & -.03 & ns \\
\hline
\end{tabular}




\section{$\underline{\text { Deductions }}$}

For non-compliance in Deduction claims, all three steps of the regression analysis explained significant portions of variance, so that we focus on step 3 again (see Table 6). Out of the four background variables, Age had a significant effect $(\beta=-.11 ; \underline{p}<.001)$, indicating that, as for Income, younger respondents reported being less compliant and less truthful in their deduction claims. Sex had a close to significant effect $(\beta=-.05 ; \mathrm{p}=.054)$, with male respondents again reporting less compliance than females.

Inclusive Identification had a negative 'average effect' $(\beta=-.07 ; \mathrm{p}=.034)$, in line with hypothesis 1. Respondents strongly inclusively identified reported being more compliant. Deterrence again had a significant negative effect $(\beta=-.15 ; \mathrm{p}<.001)$; this effect was not further moderated by the interaction with Inclusive Identification and constituted evidence for hypothesis $2 \mathrm{a}$ rather than hypothesis $2 \mathrm{~b}$. However, the findings for the other self-interest variable supported the more specific hypothesis $2 \mathrm{~b}$. As was the case for Extra Income, the interaction effect involving Outcome Favourability was significant and positive $(\beta=.06 ; \underline{p}<$ .043). Respondents who identified less rather than more strongly with Australians were more outcome-oriented because they were more compliant when tax decisions were in their favour (simple slopes: -.15 vs. -.04 ).

Moreover, perceived Procedural Justice was related to greater tax compliance only for respondents who identified strongly with Australians, whereas it was rather positively related to non-compliance for the less identified (interaction effect: $\beta=-.11 ; \mathrm{p}<.001$; simple slopes: -.08 vs. .03); this result supported hypothesis $3 \mathrm{~b}$. Similarly, the close to significant interaction effect involving the squared Distributive Injustice measure $(\beta=.03 ; \underline{p}=.054)$ reflects the finding that perceived distributive justice was related to greater compliance for those strongly identified as Australians, but not so for less identified respondents (simple slopes: .04 vs. -.02). This result paralleled the finding for Extra Income and supported hypothesis $4 \mathrm{~b}$. There was no significant effect involving perceptions of Macro-Injustice. 
Table 6: Hierarchical regression analyses for tax non-compliance in deduction claims

\begin{tabular}{lccc}
\hline & Step 1 & Step 2 & Step 3 \\
\hline$\underline{\mathrm{R}^{2}}$ & .020 & .055 & .071 \\
$\underline{\mathrm{R}}$ change & & .035 & .016 \\
$\underline{\text { Fchange ( } \underline{\mathrm{dfs}})}$ & $6.57(4,1316)$ & $7.09(7,1309)$ & $3.76(6,1303)$ \\
$\underline{\text { Sig. Fchange }}$ & .000 & .000 & .001 \\
\hline
\end{tabular}

\begin{tabular}{|c|c|c|c|c|c|c|}
\hline & $\beta$ & $\mathbf{p}$ & $\beta$ & p & $\beta$ & $\mathbf{p}$ \\
\hline Age & -.14 & .000 & -.11 & .000 & -.11 & .000 \\
\hline Sex & -.07 & .013 & -.05 & .054 & -.05 & .054 \\
\hline Personal Income & -.05 & $\underline{\mathrm{ns}}$ & -.06 & $\underline{\mathrm{ns}}$ & -.05 & $\underline{\mathrm{nS}}$ \\
\hline Family Income & .00 & $\underline{\mathrm{ns}}$ & -.02 & $\underline{\mathrm{ns}}$ & -.01 & $\underline{\mathrm{nS}}$ \\
\hline Identification & & & -.02 & $\underline{\mathrm{ns}}$ & -.07 & .034 \\
\hline Deterrence & & & -.16 & .000 & -.15 & .000 \\
\hline Outcome Fav. & & & -.11 & .001 & -.09 & .003 \\
\hline Procedural J. & & & .04 & $\underline{\mathrm{ns}}$ & .03 & $\underline{\mathrm{ns}}$ \\
\hline Distributive. Inj. & & & .04 & $\underline{\mathrm{ns}}$ & .06 & .041 \\
\hline Distrib. Inj. Squared & & & -.00 & $\underline{\mathrm{ns}}$ & .01 & $\underline{\mathrm{nS}}$ \\
\hline Macro-Injustice & & & .04 & $\underline{\mathrm{ns}}$ & .04 & $\underline{\mathrm{nS}}$ \\
\hline Id. $\times$ Deterrence & & & & & .00 & $\underline{\mathrm{nS}}$ \\
\hline Id.X Outcome Fav. & & & & & .06 & .043 \\
\hline Id.XProc. J. & & & & & -.11 & .001 \\
\hline Id. $\times$ Distr. Inj. & & & & & .03 & $\underline{\mathrm{nS}}$ \\
\hline Id.XD. Inj. Squared & & & & & .03 & .054 \\
\hline Id. $\times$ Macro-Injustice & & & & & .01 & $\underline{\mathrm{nS}}$ \\
\hline (Constant) & -.03 & ns & -.03 & ns & -.03 & ns \\
\hline
\end{tabular}




\section{$\underline{\text { Tax minimisation }}$}

For measures of Tax Minimisation, steps 1 and 2 of the regression analysis accounted for a significant portion of the variance explained, while the interaction terms introduced in step 3 did not (see Table 7). We therefore focus on step 2. The positive impact of Age $(\beta=.11 ; \underline{p}=$ .001 ) indicates that, in contrast to compliance in deduction claims and income reporting, older respondents reported they were less compliant and more likely to minimise their tax. Personal Income as well as Family Income were both positively related to tax minimisation ( $\beta=.13 ; \underline{p}<.001$ and $\beta=.17, \underline{p}<.001$, respectively). In contrast to the findings for Income and Extra Income, respondents with higher Personal Income or higher Family Income reported using tax minimisation strategies to a greater extent than lower income respondents. The only other significant predictor was Outcome Favourability; its negative effect $(\beta=-$ $.11 ; \mathrm{p}<.001)$ supported hypothesis $2 \mathrm{a}$. When respondents perceived tax decisions to be in their favour, they were less likely to use tax minimisation strategies. 
Table 7: Hierarchical regression analyses for tax minimization

\begin{tabular}{|c|c|c|c|c|c|c|}
\hline & \multicolumn{2}{|c|}{ Step 1} & \multicolumn{2}{|c|}{ Step 2} & \multicolumn{2}{|c|}{ Step 3} \\
\hline$\underline{\mathrm{R}^{2}}$ & \multicolumn{2}{|c|}{.075} & \multicolumn{2}{|c|}{.089} & \multicolumn{2}{|c|}{.091} \\
\hline$\underline{\mathrm{R}^{2} \text { change }}$ & & & \multicolumn{2}{|c|}{.014} & \multicolumn{2}{|c|}{.002} \\
\hline Fchange ( $\underline{\mathrm{dfs}})$ & \multicolumn{2}{|c|}{$27.20(4,1340)$} & \multicolumn{2}{|c|}{$2.94(7,1333)$} & \multicolumn{2}{|c|}{$.53(6,1327)$} \\
\hline Sig. Fchange & \multicolumn{2}{|c|}{.000} & \multicolumn{2}{|c|}{.005} & \multicolumn{2}{|c|}{.784} \\
\hline & $\beta$ & p & $\beta$ & p & $\beta$ & p \\
\hline Age & .09 & .004 & .11 & .001 & .11 & .000 \\
\hline Sex & -.04 & $\underline{\mathrm{ns}}$ & -.03 & $\underline{\mathrm{ns}}$ & -.03 & $\underline{\mathrm{ns}}$ \\
\hline Personal Income & .13 & .000 & .12 & .001 & .13 & .001 \\
\hline Family Income & .17 & .000 & .16 & .000 & .16 & .000 \\
\hline Identification & & & .02 & $\underline{\mathrm{ns}}$ & .03 & $\underline{\mathrm{ns}}$ \\
\hline Deterrence & & & -.04 & $\underline{\mathrm{ns}}$ & -.04 & $\underline{\mathrm{nS}}$ \\
\hline Outcome Fav. & & & -.11 & .000 & -.11 & .001 \\
\hline Procedural J. & & & .02 & $\underline{\mathrm{ns}}$ & .02 & $\underline{\mathrm{ns}}$ \\
\hline Distributive. Inj. & & & .05 & $\underline{\mathrm{ns}}$ & .05 & $\underline{\mathrm{ns}}$ \\
\hline Distrib. Inj. Squared & & & .02 & $\underline{\mathrm{ns}}$ & .02 & $\underline{\mathrm{ns}}$ \\
\hline Macro-Injustice & & & -.04 & $\underline{\mathrm{ns}}$ & -.04 & $\underline{\mathrm{nS}}$ \\
\hline Id. $\times$ Deterrence & & & & & .04 & ns \\
\hline Id. $\times$ Outcome Fav. & & & & & .03 & $\underline{\mathrm{ns}}$ \\
\hline Id.XProc. J. & & & & & -.01 & $\underline{\mathrm{nS}}$ \\
\hline Id. $\times$ Distr. Inj. & & & & & -.02 & $\underline{\mathrm{ns}}$ \\
\hline Id. $\times$ D. Inj. Squared & & & & & .00 & $\underline{\mathrm{ns}}$ \\
\hline Id. $\times$ Macro-Injustice & & & & & -.00 & $\underline{\mathrm{ns}}$ \\
\hline (Constant) & -.02 & ns & -.04 & ns & -.05 & ns \\
\hline
\end{tabular}




\section{Discussion}

The present study used a survey methodology to study the impact of self-interest and justice perceptions on self-reported tax compliance, with a particular focus on the moderating role of inclusive identification. The study tested predictions derived from the group value approach to procedural justice (Tyler et al., 1997) and the categorisation approach to distributive justice (Wenzel, 2000a, in press) concerning the impact of social identity on people's justice motivation versus outcome orientation. The findings of the study speak to three issues, namely (1) the phenomenon of tax compliance, (2) theories of justice motivation and (3) theory and practice of compliance enforcement and regulation.

\section{The phenomenon of tax compliance}

The present study yielded evidence to support the necessity of differentiating forms of tax compliance (Kidder \& McEwen, 1989). Both the factor analysis and the differential regression findings show that tax compliance is not a homogeneous set of behaviours. The factor analysis differentiated between tax compliance in the reporting of remuneration income (cash and non-cash), the reporting of extra (non-remuneration) income, claims for deductions and tax minimisation strategies. The regression analyses showed that some predictors had different effects depending on the form of compliance investigated. The findings support the view that forms of tax compliance need to be distinguished conceptually if we want to better understand and predict this phenomenon (Braithwaite et al., 2001).

\section{Background variables}

Regarding the demographic variables considered in this research, sex of respondents contributed significantly to the prediction of tax compliance in income reporting and deduction claims, but not the other two forms of tax compliance. The results are consistent with previous findings that men tend to be less compliant than women (e.g., Kinsey \& Grasmick, 1993; Mason \& Calvin, 1978; Porcano, 1988; Vogel, 1974). Further, the present study revealed negative relationships between respondent age and non-compliance in income reporting and deduction claims. In line with most earlier findings, older respondents tended 
to be more compliant (e.g., Kinsey \& Grasmick, 1993; Mason \& Calvin, 1978; Tittle, 1980; Vogel, 1974). However, other studies found either no relationship between age and tax compliance (Porcano, 1988), the reverse relationship (Wallschutzky, 1984), or even a curvilinear relationship (Song \& Yarbrough, 1978). Likewise, the present study yielded a positive relationship between age and non-compliance in terms of tax minimisation. These findings suggest that the impact of age depends on the specific form of taxpaying behaviour, which may also account for earlier empirical inconsistencies. For instance, age may be correlated with different opportunities to avoid tax. Older people may have acquired more assets that allow for strategies of tax minimisation, whereas younger people are more likely to be in the workforce and thus have access mainly to strategies of under-reporting of income and exaggeration of deductions.

The effects for personal income and family income can also be explained in terms of differential opportunities, although income level is confounded with many other variables (most notably, the tax rate). Income level was related to greater compliance in terms of reporting of income and extra income, in line with some previous research (e.g., Clotfelter, 1983). However, respondents with higher personal income or higher family income reported they would pursue strategies of tax minimisation to a greater extent than did lower income respondents. This finding supports the intuition that high-status taxpayers have greater access to such effective but relatively low-risk strategies (Roth et al., 1989). In contrast, respondents with lower income have to confine themselves to options of under-reporting income and extra income; importantly, they are also more likely to be recipients of cash payments and government allowances and thus under-reporting constitutes an available opportunity.

\section{$\underline{\text { Self-interest, justice and identity }}$}

Regarding the effects of self-interest, justice and identity variables, the regression results yielded, broadly speaking, two different patterns for the four forms of tax compliance. Noncompliance with regard to income reporting and tax minimisation were exclusively predicted by self-interest variables, whereas non-compliance in reporting of extra income as well as deduction claims were additionally influenced by identification and, interacting with identification, perceptions of justice. This pattern seems to suggest two kinds of tax non- 
compliance, namely, non-compliance for instrumental reasons and non-compliance out of protest (similar to what Kidder \& McEwen, 1989, called asocial and brokered noncompliance versus symbolic non-compliance). Income under-reporting and tax minimisation seem to follow exclusively instrumental considerations. Indeed, both seem to share the characteristic of not being considered illegitimate at all. Tax minimisation strategies are often conceived of as legal ways of reducing one's tax, even though not conducive to the integrity of the tax system. Income under-reporting (in particular, of cash income) is widely considered a trivial offence, as 'everybody does it' to some extent and as it is widely accepted in at least certain occupations (Sigala, 1999). Of course, under-reporting is nonetheless illegal, which might be the reason why it was influenced by perceived deterrence, while tax minimisation was not. More importantly, however, it seems plausible that, because tax minimisation and income under-reporting are considered acceptable and system-inherent behaviour, they are rather determined by opportunity and cost-benefit calculations and less so by considerations of social responsibility and justice. If they are not considered illegitimate and system-opposing, they can hardly be acts of protest against the system and its injustices.

In contrast, under-reporting of extra income and incorrect deduction claims were additionally determined by social factors; that is, level of inclusive identification and perceptions of justice. Because extra income (e.g., pensions) is usually more easily traceable than cash income (as an instance of remuneration income), namely due to the paper trail and the cooperation between the Tax Office and other government agencies or banks, noncompliance in extra income would seem a more explicit disagreement with the system and to require justification to oneself. Also, compared to tax on remuneration income, taxation of extra income (e.g., interest or government allowances) might be regarded as more unfair because savings have already been taxed as income, and tax on allowances, it could be argued, undermines their purpose of alleviating neediness. Hence fairness motivations may be more relevant for non-compliance in extra income. Likewise, false deduction claims are not simply an omission of a required behaviour (as is the case for under-reporting), but rather an explicit 'lie' and attempt to mislead the Tax Office. Again, it would require a justification or motivation that could be based on the perceived unfairness of the tax system. Thus it makes sense that non-compliance regarding extra income and deductions are determined more by social factors and system-related discontent. 
Specifically, for these two forms of non-compliance, the analysis yielded an effect of inclusive identification. The finding supports the prediction derived from social dilemma research that inclusive identification promotes cooperation (Brewer \& Schneider, 1990). When people identify with their country, they may view it and its representatives more positively, have greater trust in its authorities and feel more responsibility for the fate of their fellow citizens (see Kramer, Brewer \& Hanna, 1996). In fact, because they identify with their group, their sense of self is transformed into a more inclusive one (Turner, Oakes, Haslam \& McGarty, 1994) and, as a consequence, their self-interests are transformed as well to include the interests and welfare of other members (Brewer, 1991; Morrison, 1997). The interaction effects between outcome favourability and identification constitute evidence for these more specific predictions. Concern about individual outcomes impacted on tax compliance only for respondents who did not identify with their collective; highly identified respondents seemed to have transcended their concern for personal profits.

For under-reporting extra income, a similar interaction effect between deterrence and identification emerged, further supporting the theoretical argument. Moreover, this result is interesting in that it suggests that the effectiveness of deterrence is conditional, although it is probably the most advocated and certainly the most practised enforcement strategy towards tax compliance. In fact, on closer inspection of the regression results, for low inclusive identification ( -1 standard deviation) the effective regression weight for deterrence is -.16 , thus reflecting a substantial deterrence effect. However, for high inclusive identification $(+1$ standard deviation) the effective regression weight for deterrence is +.02 ; deterrence appears ineffective for those highly identified with the inclusive category. This finding may contribute to a better understanding of the inconsistent results for deterrence effects (see the discussion earlier). It certainly supports the notion that regulation needs to be more responsive to the conditions, attitudes and motivations of those to be regulated (Braithwaite \& Braithwaite, 2000). We will return to this issue below.

Likewise, the present research yielded evidence that perceptions of justice can have a significant impact on tax compliance. More importantly, the findings again might help resolve some of the inconsistencies of previous research on this issue (see the discussion earlier). In the present study, justice concerns were only relevant to two out of four forms of tax compliance. As argued before, it might be the case that only these two forms of tax non- 
compliance are considered deviant behaviour; and as instances of deviance, they require extra motivation (e.g., legitimate resentment due to felt injustice) or, conversely, are inhibited by considerations of justice or fairness. Further, even in these two cases, the impact of justice perceptions on tax compliance depended on the respondents' degree of identification with their nation, being the relevant inclusive category in this context. This leads us to a more general discussion of the nature of justice motivation.

\section{The basis of justice motivation}

The finding that perceptions of justice were positively related to tax compliance only for those respondents who identified strongly with the inclusive category was predicted on the basis of the group value approach to procedural justice (Tyler et al., 1997) and the categorisation approach to distributive justice (Wenzel, 2000a, in press) respectively. Both theories refer to social identity theory (Tajfel \& Turner, 1986) and self-categorisation theory (Turner et al., 1987) as their theoretical background. Both argue that concerns for justice are not simply based on one's motivation to maximise outcomes, through procedures that allow for some control or through distributions that are in one's favour, respectively; rather, justice is based on identity processes.

The group value approach argues that people are concerned about procedural justice, specifically about respectful, unbiased and trustworthy treatment by authorities, because it is indicative of their inclusion and standing in their social group. It has implications for their social identity in terms of the category they share with the authorities and within which the procedures are applied, but only if they regard this category as relevant to their selfdefinition (see Tyler \& Smith, 1999). Huo et al. (1996) and Smith and Tyler (1996) demonstrated that procedural justice was related to favourable evaluations of authorities and their decisions as well as the obligation to obey and follow them, when respondents identified with the inclusive category.

The present research corroborates these findings and extends them to the area of tax compliance. Taxpayers were more compliant with tax laws when they identified with Australians and thought they were treated fairly and respectfully by the tax authorities. Following the group value approach, we can conclude that taxpayers want to have their 
rights as citizens respected and their voice considered (as much as others' voices are considered) when they identify as citizens of Australia. If their status as Australian citizens is important to them, they want it to be respected and acknowledged. When authorities convey such respect and acknowledgement, taxpayers are more compliant irrespective of whether or not decision outcomes are favourable to them. While the present data supported this interactive effect of procedural justice and identification, it must be acknowledged however that procedural justice had an unexpected positive 'average effect' (across levels of identification) on under-reporting of extra income (for a similar finding, see Porcano, 1988). It is not clear why this effect occurred. Perhaps procedural fairness induced perceptions of benevolence and trustworthiness of the Tax Office that let taxpayers anticipate little punishment for their tax evasion. But then it remains unclear why this should have been the case for one but not the other forms of tax compliance.

The categorisation approach (Wenzel, 2000a, in press) argues that identity concerns are likewise the basis of the distributive justice motive. When people identify with the inclusive category that defines the boundaries of the allocation problem and includes all potential recipients, they may respond in two ways. They either want to be treated equally to others, as this acknowledges the inclusion and identity they share with other members, or they want the inclusive category to be differentiated, and members to be differentially treated, along dimensions which they consider important value dimensions of that category and defining attributes of their identity. So, irrespective of the specific content of the distributive justice notions, inclusive identification drives the motivation to see these justice notions realised. Because entitlements are derived from the inclusive category membership, violation of entitlements may lead to social protest due to injustice felt, if there is sufficient identification with the inclusive category (Wenzel, 2000a).

Previous empirical findings, however, were not always consistent with this view. For instance, Tyler (1994) and Smith and Tyler (1996) argue and provide evidence that distributive justice was more strongly based on instrumental concerns and self-interest, while procedural justice was mainly based on relational and identity concerns (as just discussed). In contrast, Wenzel (2000a) reports evidence for the categorisation approach in a study following the reunification of Germany. East Germans who identified more rather than less strongly as Germans felt entitled to a better economic situation (i.e., more equal to the West 
German one); and those East Germans who felt that their entitlements were violated and identified strongly as Germans showed more signs of social protest. However, there was no evidence for the equivalent interaction effect involving procedural justice, as the group value approach would have predicted. This could have been due to the specific political context of the study (Wenzel, 2000a). The present research now yielded evidence for both the group value approach and the categorisation approach to distributive justice.

While Smith and Tyler (1996) collapsed measures of distributive justice and instrumental evaluations, on the one hand, and measures of procedural justice and relational evaluations on the other, the present study went to great lengths to separate aspects of outcome favourability and distributive justice. It used separate predictors of outcome favourability to partial out their effects, and tested for curvilinear effects of the bipolar distributive justice measure while controlling for linear effects (of favourability). Perhaps as a consequence of this careful procedure, the present study yielded evidence for the categorisation approach. When taxpayers considered their tax burden to be unfair and they identified with the inclusive category, they reported less compliant taxpaying behaviour (in terms of extra income under-reporting and deduction claims).

However, predictions were not confirmed for the macro-aspect of distributive justice. Indeed, there were no statistically significant effects for perceived macrojustice at all. We might conclude that the respondents in our study were less concerned about macrojustice issues (and, as a consequence, there could be no support for the categorisation approach). However, it might also be the case that the operationalisation of macrojustice in the present study was suboptimal, had a considerable overlap with self-interest and was not as precise as the measure of microjustice. First, one of the two aspects of macrojustice addressed in this study did not explicitly ask about justice, but rather one's satisfaction with or preferences for government spending. Taxpayers might base their spending preferences on the extent to which they personally profit from various budget items (Sears \& Citrin, 1982). Thus satisfaction is not the same as feelings of justice and may rather involve aspects of outcome favourability; the same problem applies to a number of earlier studies (e.g., Alm et al., 1993; Alm, McClelland \& Schulze, 1992). Unlike the case of distributive microjustice, there were no specific controls for the impact of self-interest. Second, the measure of vertical injustice (i.e., individual standard deviations of bipolar justice judgments for tax burdens of different 
societal groups) might have been a too subtle measure, less transparent to respondents and thus more difficult for them to consciously express their opinion with. Further research is required to clarify the role of macrojustice for tax compliance and the psychological basis of macrojustice concerns.

\section{Compliance enforcement and regulation}

Concerning practices of enforcement and theories of regulation in general, the present findings clearly suggest that there are alternatives to deterrence and material incentives (Grasmick \& Bursik, 1990; Scholz, 1998; Smith \& Stalans, 1991). In fact, the results show that, for certain forms of compliance, deterrence may be effective only for taxpayers who do not identify with the inclusive category. Likewise, outcome favourability could be considered a proxy to material incentives, because taxpayers for whom the tax decisions were favourable had an incentive to comply with and support the tax system. Again, with even more convincing evidence than for deterrence, outcome favourability (i.e., material profitability) worked in certain cases only for those taxpayers who did not identify with their country or nation. Importantly, the segment of less identified taxpayers was clearly a minority. Thus conventional enforcement strategies of deterrence and material incentives seem to work only for a minority of taxpayers. It appears that deterrence and incentives may be effective only for taxpayers who do not identify with the system and its authorities, perceive a social rift between regulators and themselves and 'disengage' with the authorities (Braithwaite, 1995; Braithwaite \& Braithwaite, 2000). In contrast, the majority of taxpayers who feel some kind of shared identity with the authorities seem to be more concerned about justice of the tax system and fairness of their treatment, irrespective of material consequences.

In order to advance more cooperative regulatory strategies built on a system of consensual justice notions, we can derive the following suggestions from the present findings. First, perceptions of justice and fairness played a role for only two of the four forms of tax compliance, namely, those two forms that were more clearly illegal, illegitimate and unacceptable. Hence regulators must clearly define certain taxpaying behaviour as illegal; and they must use social norms and informal beliefs to convey that such behaviour is illegitimate, unacceptable and irresponsible. Or, given that norms become effective through 
how they are perceived (rather than as they 'truly' are), regulators might have to correct for misperceptions of relevant social norms (Wenzel, 2001a, 2001b).

Second, perceptions of justice and fairness affected taxpaying behaviour positively only when there was sufficient identification with the inclusive category (and thus its representatives). Hence the regulators must build a cooperative relationship with the regulatees; they must gain sympathy, respect and trust, and build on a consensual understanding of shared goals and values. Clearly, such a relationship is difficult to shape, in particular by a governmental enforcement agency like the Tax Office that is often seen almost through a party-political lens. However, there is scope for managing a better relationship. In this context, it must be stressed that the theoretical analysis presented in this paper focused on only one causal direction out of a possibly more complex and cyclical web of causal relationships. Justice motivations may not only follow from inclusive identification; rather, the satisfaction of these motivations may increase inclusive identification. For instance, the group value approach (Tyler et al., 1997; Tyler \& Lind, 1990) assumes that procedurally fair treatment increases feelings of inclusion and identification with the inclusive category and its authorities. Similarly, the categorisation approach (Wenzel, 2000b) assumes that, while entitlements are deduced from the inclusive category, treatment in accordance with entitlements induces self-categorisation in terms of the category from which the entitlements are derived. These propositions need to be tested in future research, preferably with longitudinal designs.

Third, regulators must nurture the regulatees' feelings of justice and fairness. They must treat regulatees with dignity and respect, consult widely and equally for their opinions, and demonstrate that regulatory actions ultimately aim at the integrity and fairness of the tax system and are thus to the benefit of the collective. While it seems easier to accomplish procedural fairness in the tax arena, views about the substantial distributive justice of the tax system will always differ between groups of taxpayers. This fact, however, cannot be taken as an excuse for not pursuing the ideal of a consensually just tax system; it rather demands a constant discourse about the fairness of the tax system.

The present research certainly has limitations, in particular due to its survey methodology; these problems need not be repeated here (e.g., Hessing, Elffers \& Weigel, 1988). It needs to 
be emphasised though that the correlational data do not permit causal interpretations. Wherever in the present paper findings were put in terms of causal directionality, such interpretations stem from the surplus of the underlying theory, but cannot be inferred from the data. A further problem of the study appears to be the general weakness of effects and the modest amount of variance explained. Part of the problem is certainly the small variation in the dependent variables, as the large majority of respondents stated that they were compliant and cooperative taxpayers. Part of the problem may also be the fact that self-report measures are burdened with social desirability tendencies and, in this case, perhaps the actual fear of being identified and targeted as a consequence of one's answers, detracting from the validity of the measures.

However, the present research did not intend to speak directly to practical implications but rather address theoretical questions. In this respect, the study yielded some significant and instructive findings. Our confidence in the reliability and validity of the results is furthermore reinforced by the fact that the findings replicated earlier preliminary analyses based on the first half of the sample (Wenzel, 2000c). Overall, the present study encourages a strongly theory-driven analysis of compliance and regulation processes that acknowledge, beyond our widely shared materialism, human concerns for fairness, justice and identity. 


\section{REFERENCES}

Aiken, L.S. \& West, S.G. (1991). Multiple regression: Testing and interpreting interactions. Newbury Park, CA: Sage.

Allingham, M. \& Sandmo, A. (1972). Income tax evasion: A theoretical analysis. Journal of Public Economics, 1, 323-338.

Alm, J., Jackson, B.R. \& McKee, M. (1993). Fiscal exchange, collective decision institutions, and tax compliance. Journal of Economic Behavior and Organization, 22, 285303.

Alm, J., McClelland, G. \& Schulze, W. (1992). Why do people pay taxes? Journal of Public Economics, 48, 21-38.

Andreoni, J., Erard, B. \& Feinstein, J. (1998). Tax compliance. Journal of Economic Literature, 36, 818-860.

Braithwaite, V. (1995). Games of engagement: Postures within the regulatory community. Law and Policy, 17, 225-255.

Braithwaite, V. (2000). The Community Hopes, Fears and Actions Survey. Canberra: Centre for Tax System Integrity, Research School of Social Sciences, The Australian National University.

Braithwaite, V., Reinhart, M., Braithwaite, J. \& Williams, R. (2001). Measuring the extent of tax minimization and evasion. Centre for Tax System Integrity Working Paper, Australian National University, Canberra, Australia. In preparation.

Braithwaite, V. \& Braithwaite, J. (2000). An evolving compliance model for tax enforcement. In N. Shover \& J.P. Wright (Eds) Crimes of privilege. Oxford: Oxford University Press. 
Brewer, M.B. (1991). The social self: On being the same and different at the same time. Personality and Social Psychology Bulletin, 17, 475-482.

Brewer, M.B. \& Kramer, R.M. (1986). Choice behavior in social dilemmas: Effects of social identity, group size, and decision framing. Journal of Personality and Social Psychology, 50, $543-549$.

Brewer, M.B. \& Schneider, S.K. (1990). Social identity and social dilemmas. In D. Abrams \& M.A. Hogg (Eds) Social identity theory: Constructive and critical advances (pp. 169184). London: Harvester-Wheatsheaf.

Brickman, P., Folger, R., Goode, E. \& Schul, Y. (1981). Microjustice and macrojustice. In M.J. Lerner \& S.C. Lerner (Eds) The justice motive in social behavior (pp. 173-202). New York: Plenum Press.

Christensen, A. \& Hite, P. (1997). A study of the effect of taxpayer risk perceptions on ambiguous compliance decisions. The Journal of the American Tax Association, 19, 1-18.

Clotfelter, C. (1983). Tax evasion and tax rates: An analysis of individual returns. The Review of Economics and Statistics, 65, 363-373.

Cohen, J. \& Cohen, P. (1975). Applied multiple regression/correlation analysis for the behavioral sciences. Hillsdale, NJ: Erlbaum.

Cohen, R.L. (1987). Distributive justice: Theory and research. Social Justice Research, 1, $19-40$.

Cowell, F.A. (1992). Tax evasion and inequity. Journal of Economic Psychology, 13, 521543.

Cullis, J.G. \& Lewis, A. (1997). Why people pay taxes: From a conventional economic model to a model of social convention. Journal of Economic Psychology, 18, 305-321.

Dawes, R.M. (1980). Social dilemmas. Annual Review of Psychology, 31, 169-193. 
De Juan, A., Lasheras, M.A. \& Mayo, R. (1994). Voluntary tax compliant behavior of Spanish income tax payers. Public Finance, 49, 90-105.

Dubin, J.A., Graetz, M.J. \& Wilde, L.L. (1987). Are we a nation of tax cheaters? New econometric evidence on tax compliance. The American Economic Review, 77, 240-245.

Dubin, J.A. \& Wilde, L.L. (1988). An empirical analysis of federal income tax auditing and compliance. National Tax Journal, 16, 61-74.

Elffers, H. (2000). But taxpayers do cooperate! In M. van Vugt, M. Snyder, T.R. Tyler \& A. Biel (Eds) Cooperation in modern society (pp. 184-194). London: Routledge.

Falkinger, J. (1995). Tax evasion, consumption of public goods and fairness. Journal of Economic Psychology, 16, 63-72.

Fischer, C., Wartick, M. \& Mark, M. (1992). Detection probability and taxpayer compliance: A review of the literature. Journal of Accounting Literature, 11, 1-46.

Friedland, N. (1982). A note on tax evasion as a function of the quality of information about the credibility of threatened fines: Some preliminary research. Journal of Applied Social Psychology, 12, 54-59.

Friedland, N., Maital, S. \& Rutenberg, A. (1978). A simulation study of income tax evasion. Journal of Public Economics, 10, 107-116.

Gordon, J.P.F. (1989). Individual morality and reputation costs as deterrents to tax evasion. European Economic Review, 33, 797-805.

Grasmick, H.G. \& Bursik Jr, R.J. (1990). Conscience, significant others, and rational choice: Extending the deterrence model. Law and Society Review, 24, 837-861.

Haslam, S.A. (2001). Psychology in organizations: The social identity approach. London: Sage. 
Hessing, D.J., Elffers, H. \& Weigel, R.H. (1988). Exploring the limits of self-reports and reasoned action: An investigation of the psychology of tax evasion behavior. Journal of Personality and Social Psychology, 54, 405-413.

Hessing, D.J., Kinsey, K.A., Elffers, H. \& Weigel, R.H. (1988). Tax evasion research: Measurement strategies and theoretical models. In W.F. van Raaij \& G. M. van Veldhoven (Eds) Handbook of economic psychology (pp. 516-537). Dordrecht, Netherlands: Kluwer Academic Publishers.

Hite, P.A. \& Roberts, M.L. (1991). An experimental investigation of taxpayer judgments on rate structure in the individual income tax system. Journal of the American Taxation Association, 13, 47-63.

Huo, Y.J., Smith, H.J., Tyler, T.R. \& Lind, E.A. (1996). Superordinate identification, subgroup identification, and justice concerns: Is separatism the problem, is assimilation the answer? Psychological Science, 7, 40-45.

Internal Revenue Service. (1997). The individual income tax gap and accounts receivable. IRS News Release, \#FS-97-14, Internet: http://www.unclefed.com/Tax-News/1997/Nrfs97$14 . \mathrm{html}$

Kahneman, D. \& Miller, D.T. (1986). Norm theory: Comparing reality to its alternatives. Psychological Review, 93, 136-153.

Kaplan, S.E. \& Reckers, P.M.J. (1985). A study of tax evasion judgments. National Tax Journal, 38, 97-102.

Kidder, R. \& McEwen, C. (1989). Taxpaying behavior in social context: A tentative typology of tax compliance and noncompliance. In J. Roth \& J. Scholz (Eds) Taxpayer compliance, Vol. 2: Social science perspectives (pp. 47-75). Philadelphia: University of Pennsylvania Press. 
Kinsey, K.A. \& Grasmick, H.G. (1993). Did the Tax Reform Act of 1986 improve compliance? Three studies of pre- and post-TRA compliance attitudes. Law \& Policy, 15, 239-325.

Kinsey, K.A., Grasmick, H.G. \& Smith, K.W. (1991). Framing justice: Taxpayer evaluations of personal tax burdens. Law and Society Review, 25, 845-873.

Klepper, S. \& Nagin, D. (1989). Tax compliance and perceptions of the risks of detection and criminal prosecution. Law and Society Review, 23, 209-240.

Kramer, R.M., Brewer, M.B. \& Hanna, B.A. (1996). Collective trust and collective action: The decision to trust as a social decision. In R.M. Kramer \& T.R. Tyler (Eds) Trust in organizations: Frontiers of theory and research (pp. 357-389). Thousand Oaks, CA: Sage.

Lewis, A. (1982). The psychology of taxation. Oxford: Martin Robertson.

Lind, E.A., Kanfer, R. \& Earley, P.C. (1990). Voice, control, and procedural justice: Instrumental and noninstrumental concerns in fairness judgments. Journal of Personality and Social Psychology, 59, 952-959.

Lind, E.A. \& Tyler, T.R. (1988). The social psychology of procedural justice. New York: Plenum Press.

Magner, N.R., Johnson, G.G., Sobery, J.S. \& Welker, R.B. (2000). Enhancing procedural justice in local government budget and tax decision making. Journal of Applied Social Psychology, 30, 798-815.

Mason, R. \& Calvin, L.D. (1984). Public confidence and admitted tax evasion. National Tax Journal, 37, 489-496.

Mason, R \& Calvin, L.D. (1978). A study of admitted income evasion. Law and Society Review, 13, 73-89. 
Mearns, M. \& Braithwaite, V. (2001). Community Hopes, Fears and Action Survey: Survey method, sample representativeness and data quality. Centre for Tax System Integrity Working Paper No. 4, The Australian National University, Canberra, Australia.

Messick, D.M. \& Sentis, K. (1983). Fairness, preference, and fairness bias. In D.M. Messick \& K.S. Cook (Eds) Equity theory: Psychological and sociological perspectives (pp. 61-94). New York: Praeger.

Morrison, B.E. (1997). Social cooperation: Re-defining the self in self-interest. Unpublished $\mathrm{PhD}$ thesis. The Australian National University, Canberra, Australia.

Porcano, T.M. (1988). Correlates of tax evasion. Journal of Economic Psychology, 9, 47-67.

Roberts, M.L. \& Hite, P.A. (1994). Progressive taxation, fairness, and compliance. Law \& Policy, 16, 27-47.

Roth, J., Scholz, J. \& Witte, A. (1989). Taxpayer compliance, Vol. 1: An agenda for research. Philadelphia: University of Pennsylvania Press.

Scholz, J.T. (1998). Trust, taxes, and compliance. In V. Braithwaite \& M. Levi (Eds) Trust and governance (pp. 135-166). New York: Russell Sage Foundation.

Scholz, J.T. \& Lubell, M. (1998). Trust and taxpaying: Testing the heuristic approach to collective action. American Journal of Political Science, 42, 398-417.

Schwartz, R. \& Orleans, S. (1967). On Legal Sanctions. University of Chicago Law Review, 34, 274-300.

Sears, D.O. \& Citrin, J. (1982). Tax revolt: Something for nothing in California. Cambridge, Mass.: Harvard University Press.

Sheffrin, S. \& Triest, R. (1992). Can brute deterrence backfire? Perceptions and attitudes in taxpayer compliance. In J. Slemrod (Ed.) Who pays taxes and why? Tax compliance and enforcement (pp. 193-218). Ann Arbor: University of Michigan Press. 
Sigala, M. (1999). Tax compliance and social influence. Unpublished doctoral thesis. University of Exeter, UK.

Smith, H.J. \& Tyler, T.R. (1996). Justice and power: When will justice concerns encourage the advantaged to support policies which redistribute economic resources and the disadvantaged to willingly obey the law? European Journal of Social Psychology, 26, 171200.

Smith, K.W. \& Stalans, L.J. (1991). Encouraging tax compliance with positive incentives: A conceptual framework and research directions. Law and Policy, 13, 35-53.

Song, Y.-D. \& Yarbrough, T.E. (1978). Tax ethics and taxpayer attitudes: A survey. Public Administration Review, 38, 442-452.

Spicer, M.W. \& Becker, L.A. (1980). Fiscal inequity and tax evasion: An experimental approach. National Tax Journal, 33, 171-175.

Spicer, M.W. \& Lundstedt, S.B. (1976). Understanding tax evasion. Public Finance, 31, $295-305$.

Stalans, L. \& Lind, E.A. (1997). The meaning of procedural fairness: A comparison of taxpayers' and representatives' views of their tax audits. Social Justice Research, 10, 311331.

Strümpel, B. (1969). The contribution of survey research to public finance. In A.T. Peacock (Ed.) Quantitative analysis in public finance (pp. 13-22). New York: Praeger.

Tajfel, H. \& Turner, J.C. (1986). The social identity theory of intergroup behavior. In S. Worchel \& G. Austin (Eds) Psychology of intergroup relations (pp. 7-24). Chicago: NelsonHall.

Thibaut, J. \& Walker, L. (1975). Procedural justice: A psychological analysis. Hillsdale, NJ: Erlbaum. 
Tittle, C. (1980). Sanctions and social deviance: The question of difference. New York: Praeger.

Turner, J.C., Hogg, M.A., Oakes, P.J., Reicher, S.D. \& Wetherell, M.S. (1987). Rediscovering the social group: A self-categorization theory. Oxford, UK: Basil Blackwell.

Turner, J.C., Oakes, P.J., Haslam, S.A. \& McGarty, C. (1994). Self and collective: Cognition and social context. Personality and Social Psychology Bulletin, 20, 454-463.

Tyler, T.R. (1989). The psychology of procedural justice: A test of the group value model. Journal of Personality and Social Psychology, 57, 850-863.

Tyler, T.R. (1994). Psychological models of the justice motive. Journal of Personality of Social Psychology, 67, 850-863.

Tyler, T.R. (1997). The psychology of legitimacy: A relational perspective on voluntary deference to authorities. Personality and Social Psychology Review, 1, 323-345.

Tyler, T.R., Boeckmann, R.J., Smith, H.J. \& Huo, Y.J. (1997). Social justice in a diverse society. Boulder, CO: Westview.

Tyler, T.R. \& Lind, E.A. (1990). Intrinsic versus community-based justice models: When does group membership matter? Journal of Social Issues, 46, 83-94.

Tyler, T.R., Rasinski, K. \& Spodick, N. (1985). The influence of voice on satisfaction with leaders: Exploring the meaning of process control. Journal of Personality and Social Psychology, 48, 72-81.

Tyler, T.R. \& Smith, H.J. (1998). Social justice and social movements. In D.G. Gilbert, S.T. Fiske \& G. Lindzey (Eds) The handbook of social psychology (4th edn, vol. 2, pp. 595-629). Boston, MA: McGraw-Hill. 
Tyler, T.R. \& Smith, H. J. (1999). Justice, social identity, and group processes. In T.R. Tyler, R.M. Kramer \& O.P. John (Eds) The psychology of the social self (pp. 223-264). Mahwah, NJ: Erlbaum.

Varma, K.N. \& Doob, A.N. (1998). Deterring economic crimes: The case of tax evasion. Canadian Journal of Criminology, 40, 165-184.

Vogel, J. (1974). Taxation and public opinion in Sweden: An interpretation of recent survey data. National Tax Journal, 27, 499-513.

Wallschutzky, I.G. (1984). Possible causes of tax evasion. Journal of Economic Psychology, $5,371-384$.

Wallschutzky, I.G. (1985). Taxpayer attitudes to tax avoidance and evasion. Sydney: Australian Tax Research Foundation.

Wallschutzky, I.G. (1996). Issues in research methods: With reference to income tax research. Unpublished manuscript. University of Newcastle, Australia.

Walster, E., Walster, G.W. \& Berscheid, E. (1978). Equity: Theory and research. Boston: Allyn and Bacon.

Webley, P. \& Halstead, S. (1986). Tax evasion on the micro: Significant simulations or expedient experiments? The Journal of Interdisciplinary Economics, 1, 87-100.

Webley, P., Robben, H. \& Morris, I. (1988). Social comparison, attitudes and tax evasion in a shop simulation. Social Behaviour, 3, 219-228.

Weigel, R.H., Hessing, D.J. \& Elffers, H. (1987). Tax evasion research: A critical appraisal and theoretical model. Journal of Economic Psychology, 8, 215-235.

Wenzel, M. (2000a). Justice and identity: The significance of inclusion for perceptions of entitlement and the justice motive. Personality and Social Psychology Bulletin, 26, 157-176. 
Wenzel, M. (2000b). What is social about justice? Inclusive identity and group values as the basis of the justice motive. Manuscript submitted for publication.

Wenzel, M. (2000c). Justice, identity and tax compliance. Paper presented at the 1st International Conference of the Centre for Tax System Integrity, Canberra, Australia, 4-5 December, 2000.

Wenzel, M. (2001a). Misperceptions of social norms about tax compliance (1): A prestudy. Centre for Tax System Integrity Working Paper No. 7. Canberra: The Australian National University.

Wenzel, M. (2001b). Misperceptions of social norms about tax compliance (2): A fieldexperiment. Centre for Tax System Integrity Working Paper No. 8. Canberra: The Australian National University.

Wenzel, M. (in press). A social categorisation approach to distributive justice: Social identity as the link between relevance of inputs and need for justice. British Journal of Social Psychology. 


\begin{abstract}
APPENDIX
This appendix contains a complete list of the measures used for the various sub-concepts of tax compliance and justice. It details also the original scale formats and the recoding of the data if applicable.
\end{abstract}

\title{
Tax compliance
}

Income

'As far as you know, did you report all the money you earned in your 1998-99 income tax return?' $(1=\underline{\text { yes }}, 2=\underline{\text { no }})$

'Have you worked for cash-in-hand payments in the last 12 months? By cash-in-hand we mean cash money that tax is not paid on.' $(1=$ yes, $2=\underline{\text { no}}$; reverse-coded $)$

'People earn income from many different sources, [...] Think about each of the sources of income listed below and select the response that best describes your 1998-99 income tax return.' $(1=$ received none, $2=\underline{\text { did not declare it, } 3=\text { declared some, }} 4=\underline{\text { declared most }}, 5=$ declared all; recoded into 1, 2, 2, 2 and 1 respectively): (1) Salary, wages; (2) Honorariums, allowances, tips, bonuses, directors fees.

\section{Extra income}

The previous question was continued for: (3) Eligible termination payments; (4) Australian government allowances like Youth Allowance, Austudy, Newstart; (5) Australian government pension, superannuation pensions, and other pensions and annuities; (6) Interest; (7) Dividends. 


\section{$\underline{\text { Deductions }}$}

'As far as you know, did you exaggerate the amount of deductions or rebates in your 199899 income tax return?' $(1=\underline{\text { a lot }}, 2=$ quite a bit, $3=\underline{\text { somewhat }}, 4=\underline{\text { a little }}, 5=\underline{\text { not at all; }}$ reverse-coded)

'Think of the deductions and rebates you claimed in your 1998-99 income tax return. Would you say you were ...' $(1=\ldots$. absolutely confident that they were all legitimate, $2=\underline{\text { a bit }}$ unsure about some of them, $3=$ pretty unsure about quite a lot, $4=\underline{\text { haven't a clue, someone }}$ else did it; recoded into 1, 2, 2 and 2 respectively)

\section{$\underline{\text { Tax minimisation }}$}

'Some people put in a lot of effort to plan their financial affairs in order to legally pay as little tax as possible. How much effort did you or your family devote to this objective in preparing for your 1998-99 income tax return?' $(1=\underline{\text { a lot, }} 2=$ quite a bit, $3=\underline{\text { some }}, 4=\underline{\text { a }}$ little, 5 = $\underline{\text { none; }}$ reverse-coded)

'In preparing for your 1998-99 income tax return, did you look at several different ways of arranging your finances to minimise your tax?' (1 = yes, 2 = 무; reverse-coded $)$

'Below is a list of investment strategies that may provide for tax minimisation. In preparing for your 1998-99 income tax return, were you able to minimise your tax through ... (1) Negative gearing (property/shares), (2) Employee share arrangements, (3) Salary packaging, (4) Superannuation planning, (5) Warrants or leveraged investments, (6) Schemes to convert income into capital gains, (7) Tax shelters, e.g. film schemes, agricultural schemes, (8) Offshore tax havens or other international tax planning' (each with the response options yes, no, don't know what that is; coded as 1,0 and 0 respectively, and averaged over all minimisation strategies). 


\section{Deterrence}

\section{$\underline{\text { Under-reporting of cash }}$}

'Imagine yourself in this situation. You have been paid A \$5000 in cash for work that you have done outside your regular job. You don't declare it on your income tax return.' (A) "What do you think the chance are that you will get caught?' ( $1=\underline{\text { about zero [0\%], } 2 \text { = about }}$

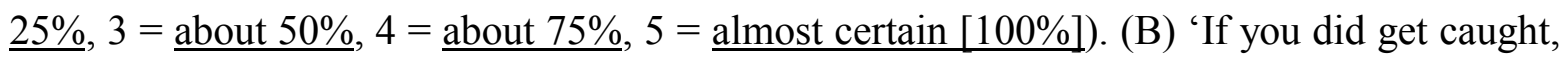
what are the chances that you would have to face the following legal consequences? (a) Taken to court + pay a substantial fine + pay the tax you owe with interest; (b) taken to court + pay the tax you owe with interest; (c) pay a substantial fine + pay the tax you owe with interest; (d) pay the tax you owe with interest' (with the same percentage scale for each item). (C) 'Look at these legal consequences again. How much of a problem would they be

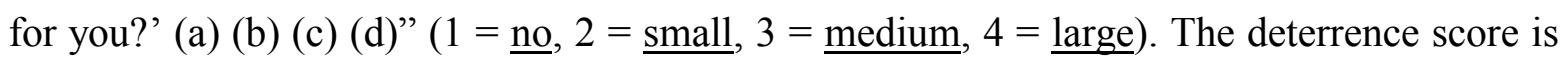
defined as $\mathrm{A} *\left(\mathrm{Ba} * \mathrm{Ca}+\mathrm{Bb}^{*} \mathrm{Cb}+\mathrm{Bc}^{*} \mathrm{Cc}+\mathrm{Bd}^{*} \mathrm{Cd}\right) / 4$.

\section{Exaggerations of deductions}

'Imagine yourself in this situation. You have claimed A \$5000 as work deductions when the expenses have nothing to do with work.' - The questions that followed were the same as for cash income and the measure was constructed equivalently.

\section{Outcome favourability}

'How often do you agree with the decisions made by the Tax Office?'; 'How often are the decisions of the Tax Office favourable to you?' (1 = $\underline{\text { almost never, }} 5$ = $\underline{\text { almost always }}$ ).

\section{Procedural justice}

$\underline{\text { Respect }}$

'The Tax Office respects the individual's rights as a citizen'; 'The Tax Office is concerned about protecting the average citizen's rights'.

Trustworthiness 
'The Tax Office considers the concerns of average citizens when making decisions'; 'The Tax Office cares about the position of taxpayers'; 'The Tax Office tries to be fair when making their decisions'.

\section{Neutrality}

'The Tax Office gives equal consideration to the views of all Australians'; 'The Tax Office gets the kind of information it needs to make informed decisions'; 'The Tax Office is generally honest in the way it deals with people'; 'The Tax Office consults widely about how they might change things to make it easier for taxpayers to meet their obligations'; 'The Tax Office goes to great lengths to consult with the community over changes to their system' (1 $=\underline{\text { strongly disagree, }}, 2=\underline{\text { disagree, }} 3=\underline{\text { neither, }} 4=$ agree, $5=\underline{\text { strongly agree, }}$, for all the procedural justice items).

\section{Distributive Justice}

\section{$\underline{\text { Micro-injustice }}$}

'Think about the people who are in the same boat as you when it comes to paying tax. In your opinion, do they pay ...?' $(1=\ldots$...much more than their fair share, $2=$ a bit more, $3=$

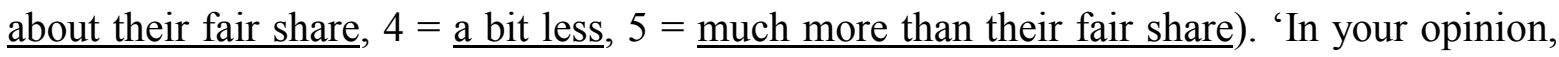
do the following people/groups pay their fair share of tax?' (same response format): (a) You, yourself; (b) Your industry/occupation group.

\section{$\underline{\text { Macro-injustice }}$}

The previous question also referred to: (3) Workers whose primary income is wage and salaries; (4) People who make a lot of money from investments; (5) Families earning less than A $\$ 20,000$ a year; (6) Families earning less than A \$100,000 a year; (7) Owner-managers of large companies; (8) Senior judges and barristers; (9) Unskilled factory workers; (10) Tradespeople; (11) Farm labourers; (12) Farm owners; (13) Doctors in general practice (GPs); (14) Chief executives of large national corporations; (15) Small business owners; (16) 
Tax agents and advisors; (17) Waitresses; (18) Surgeons. The 'vertical' justice measure was defined as the respondent's standard deviation across these items.

'The government spends taxpayers' money in many different areas. Below are just a few of these areas. For each area, do you think the government should be spending less money, keeping things as they are, or spending more money?' $(1=\underline{\text { much less }}, 2=\underline{\text { less }}, 3=\underline{\text { same }}, 4=$ more, 5 = $\underline{\text { much more; }}$ recoded into 3, 2, 1, 2 and 3 respectively): (1) Education; (2) Defence; (3) Health care; (4) Law courts and legal aid; (5) Policing; (6) Preventing illegal immigration; (7) Welfare; (8) Employment; (9) Scientific research; (10) The arts (film, music, dance); (11) Industry development. 'Overall, how dissatisfied or satisfied are you with the way the government spends taxpayers' money?' $(1=$ dissatisfied, 5 = satisfied; reverse-coded). 


\section{THE CENTRE FOR TAX SYSTEM INTEGRITY WORKING PAPERS}

No. 1. Braithwaite, V.\& Reinhart, M. The Taxpayers' Charter: Does the Australian Taxation Office comply and who benefits? Dec. 2000.

No. 2. Braithwaite, V. The Community Hopes, Fears and Actions Survey: Goals and Measures. March 2001.

No. 3. Braithwaite, V., Reinhart, M. Mearns, M. \& Graham, R. Preliminary findings from the Community Hopes, Fears and Actions Survey. April 2001.

No. 4. Mearns, M., \& Braithwaite, V. The Community Hopes, Fears and Actions Survey: Survey method, sample representativeness and data quality. April 2001.

No. 5. Sakurai, Y., \& Braithwaite, V. Taxpayers' perceptions of the ideal tax adviser: Playing safe or saving dollars? May 2001.

No. 6. Wenzel, M. The impact of outcome orientation and justice concerns on tax compliance: The role of taxpayers' identity. June 2001. 